${ }^{\mathrm{I}}$ Universidade Federal do Rio de Janeiro (UFRJ),

Programa de Pós-Graduação em Sociologia e Antropologia,

Rio de Janeiro, RJ, Brasil

joana.correa@uol.com.br

Joana Ramalho Ortigão Corrêa'

\title{
A CONSTRUÇÃO SOCIAL DO FANDANGO COMO EXPRESSÃO CULTURAL POPULAR E TEMA DE ESTUDOS DE FOLCLORE ${ }^{1}$
}

Na região que abrange o litoral sul de São Paulo e norte do Paraná ${ }^{2}$ há muitos músicos, grupos e núcleos comunitários que se dedicam à prática do fandango. Embora a noção de fandango tenha um caráter polissêmico, correntemente é definido como uma expressão popular associada à cultura "caipira" ou "caiçara", que reúne dança, com coreografias em pares e roda, e música executada por violas, rabecas (ver fotos I e II) e outros instrumentos artesanais e industriais. As músicas são também cantadas pelos próprios tocadores, com letras que mesclam tradição oral e improviso.

Os fandangos são normalmente narrados como celebrações relacionadas aos mutirões de trabalho realizados em sítios e vilas que agregam pequenas propriedades familiares, comuns tanto em áreas litorâneas como interioranas (ver foto 3 na p.4Io). Contudo, há algumas décadas, os mutirões têm se tornado eventuais e, pelo menos desde a década de I960, a prática do fandango ganhou novos circuitos de organização e produção, que envolvem a formação de grupos e associações culturais, gravação de discos e filmes, realização de oficinas para crianças e jovens, apresentações nos próprios municípios em festas tradicionais, culturais e turísticas, participação em mostras culturais nas capitais dos estados e outras localidades (ver foto 4 na p. 4II), elaboração de projetos para editais que premiam grupos e mestres, entre outros. Recentemente, o fandango foi declarado bem de referência do patrimônio cultural brasileiro no âmbito das políticas de patrimônio imaterial empreendidas pelo Instituto do Patrimônio Histórico e Artístico Nacional (IPHAN). 


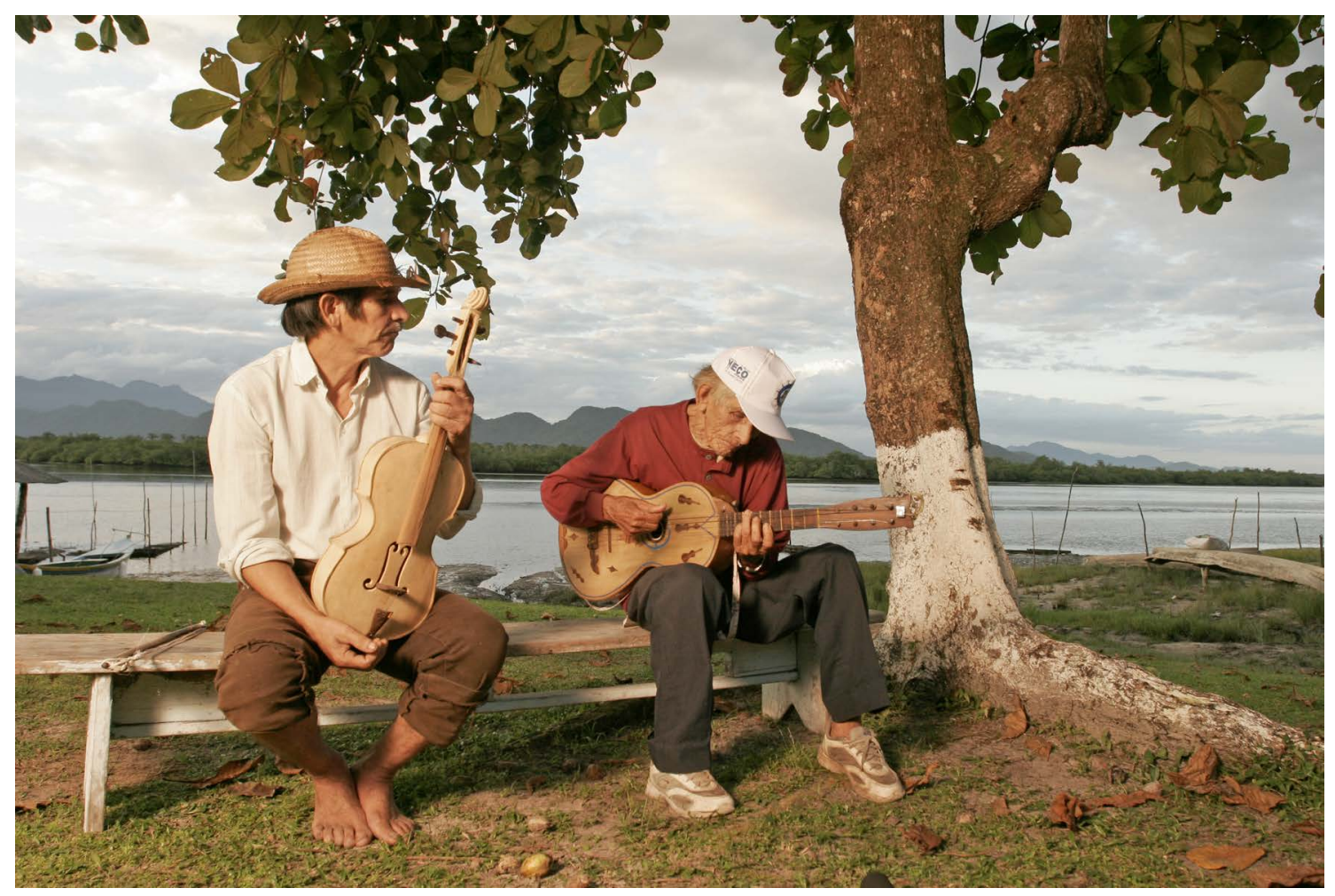

Amirton (rabeca) e Faustino Mendonça (viola) em Vila Fátima, Ilha do Superagui, Guaraqueçaba/PR.

Junho de 2005. Acervo Museu Vivo do Fandango, Associação Cultural Caburé. 


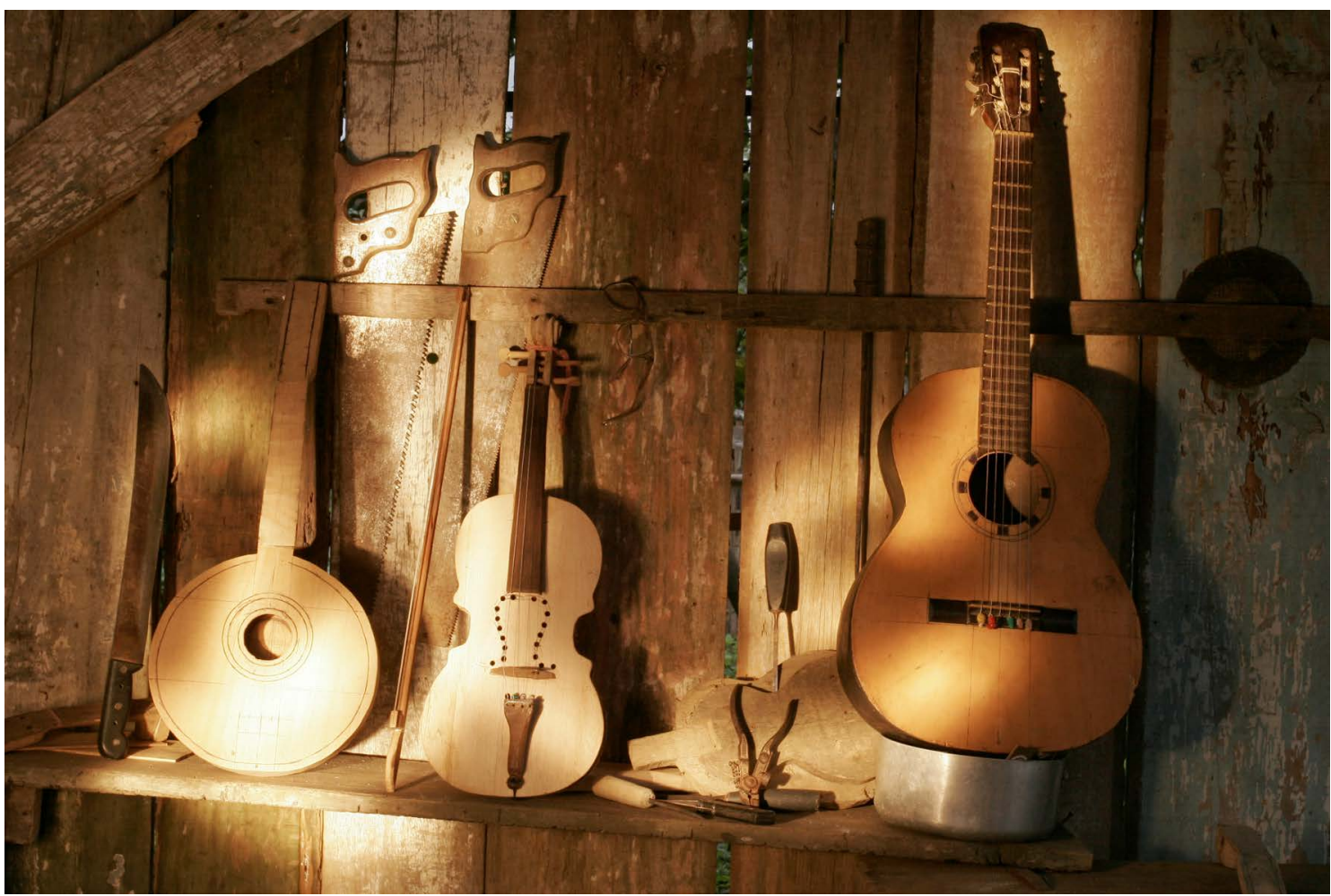

2.

Varanda, Felipe.

Instrumentos artesanais de fandango na oficina de Martinho dos Santos, em Morretes/PR.

Junho de 2005.

Acervo Museu Vivo do Fandango,

Associação Cultural Caburé. 


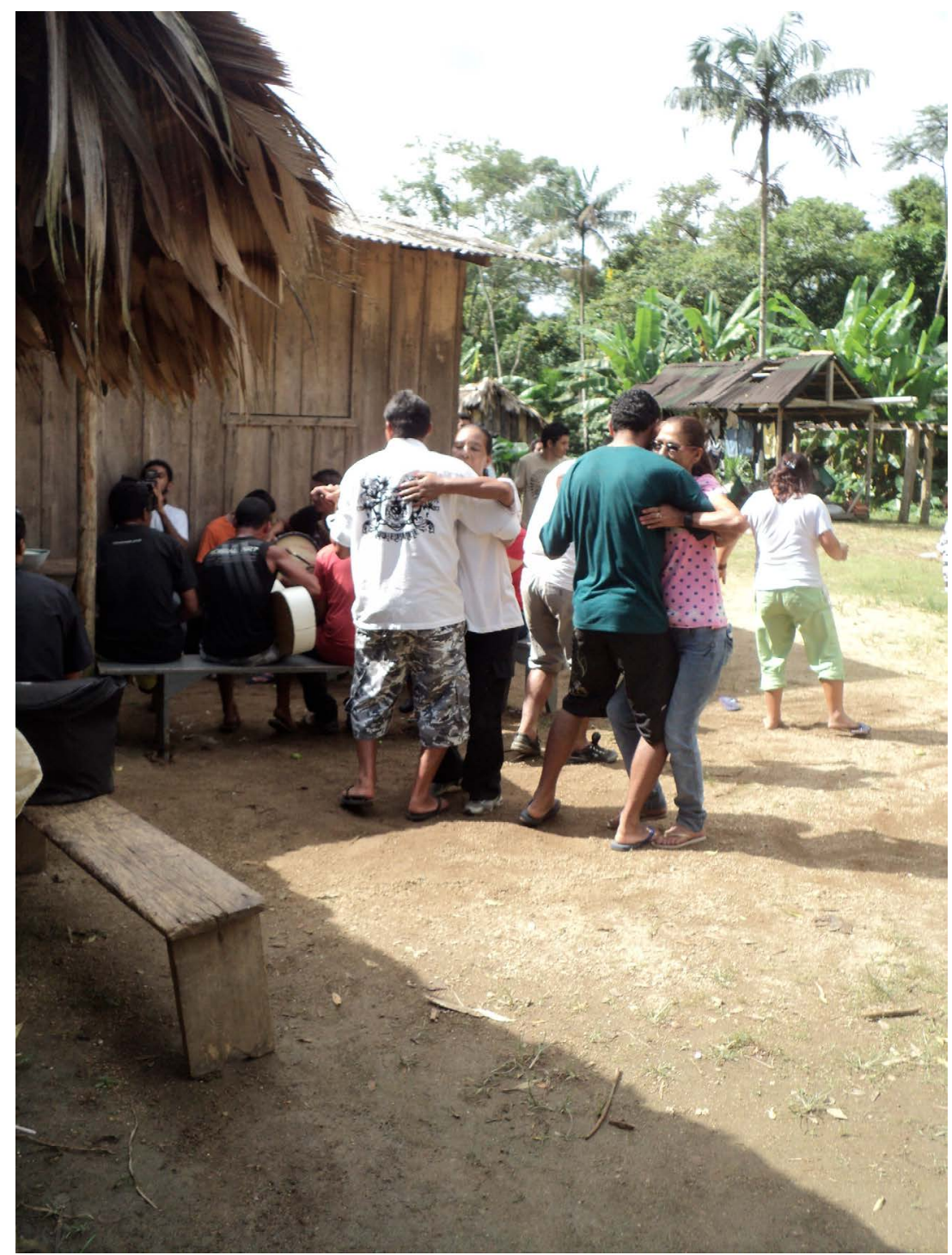

3. Corrêa, Joana

Domingueira de fandango após mutirão de colheita de arroz noVaradouro, Cananeia/SP. Janeiro de 2012 . 


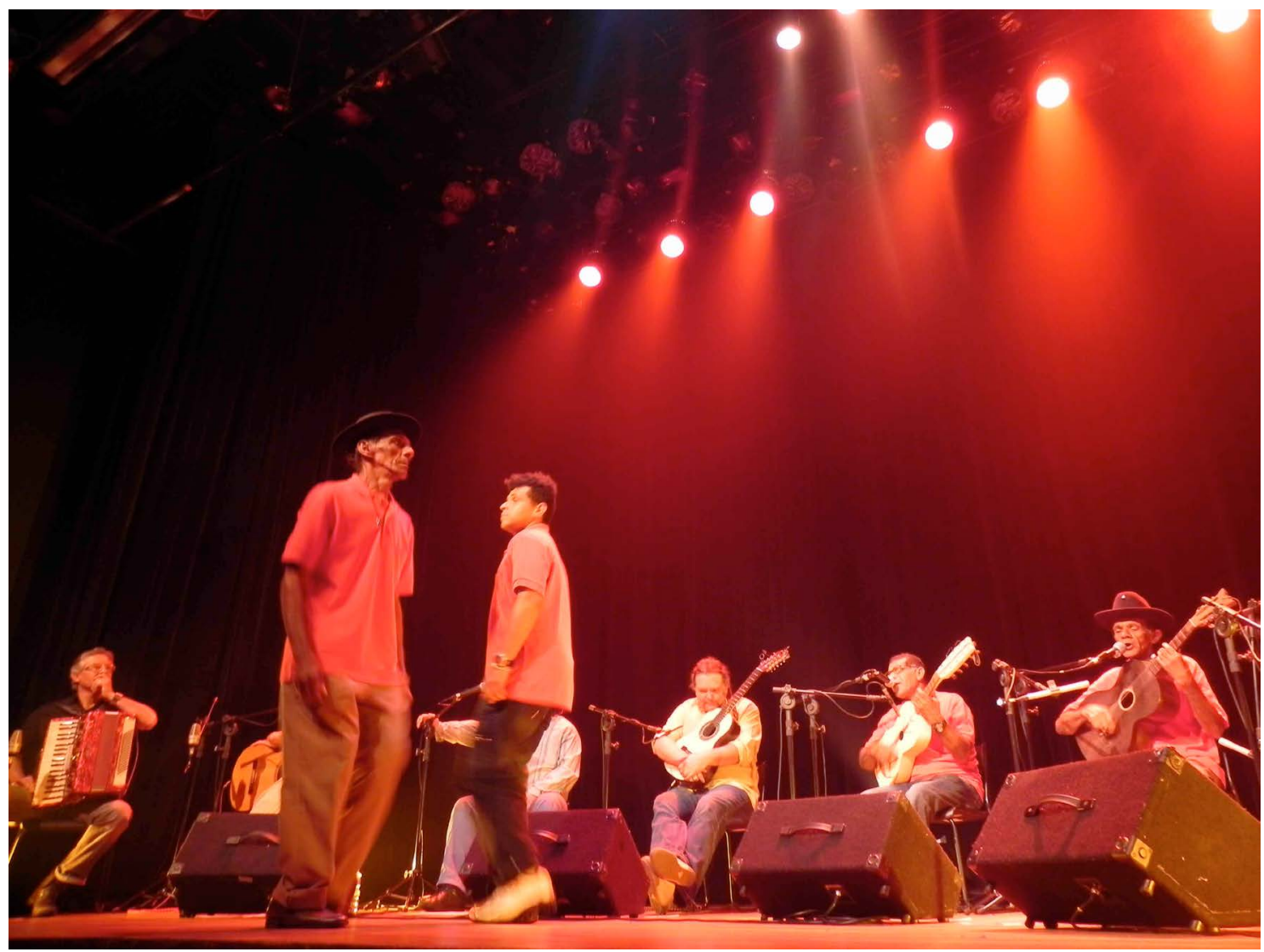

4. Corrêa, Joana

Apresentação de fandangueiros da Família Pereira, de Cananeia/SP e Guaraqueçaba/PR, com integrantes do grupo paraense Viola Quebrada em um centro cultural na cidade de São Paulo/SP.

Janeiro de 2012. 
Embora a prática do fandango tenha encontrado novos trânsitos em circuitos amplificados de relações, muitos daqueles que estão envolvidos com o fandango, tais como músicos, dançadores e articuladores culturais, procuram assegurar certos fundamentos que o caracterizam como expressão emblemática de populações tradicionais de São Paulo e do Paraná. Ao longo dos anos em que me dediquei a pesquisas na região, percebi que os relatos e descrições sobre o fandango ora o organizam como um sistema fechado que se explica por sua própria prática no contexto dos sítios, ora o inscrevem em sistemas mais amplos relacionados às concepções de folclore e cultura popular. Em meio aos encontros, conversas e leituras sobre o tema, os significados atribuídos ao fandango foram revelando muitas camadas de processos dialógicos elaborados na interação de práticas e concepções nativas com outras esferas de produção de conhecimento e formas de sociabilidade. ${ }^{3}$

A partir da primeira metade do século XX, o fandango e os modos de vida das comunidades locais começam a aparecer como temas de investigação de gerações de pesquisadores, em especial no contexto dos estudos do folclore que colaboraram sobremaneira para a formação do interesse intelectual sobre as expressões populares no país. A proposta deste artigo é pensar sobre a participação decisiva dos estudos de folclore no estabelecimento do fandango como um tema de interesse para além de seu contexto local, evidenciando diferentes concepções e perspectivas de registro dos estudiosos.

Tais estudos, nas décadas de I920 e I930, ganham relevância no âmbito do modernismo brasileiro, com as pesquisas de Mário de Andrade sobre o assunto, e também no contexto do Movimento Folclórico Brasileiro, entre os anos I947 e I964 (Vilhena, I997). Embora nos anos I960-I970 os estudos de folclore tenham sido afastados do convívio com as ciências sociais que firmavam sua institucionalização nas universidades no centro-sul do país, Vilhena (I997) e Cavalcanti \& Vilhena (2012) mostraram como eles integraram o período de formação das ciências sociais no Brasil. Especialmente entre as décadas de 1930 e I960, muitos intelectuais - além de Mário de Andrade, Edison Carneiro, Manuel Diégues Jr., Théo Brandão, Thales de Azevedo, entre tantos outros - transitavam por terrenos compartilhados entre o folclore e as ciências sociais, que eram então campos contíguos de diálogos.

Imbuídos de preocupações quanto aos efeitos nocivos da modernidade, esses intelectuais buscaram coletar, registrar e fomentar as expressões populares atuando também junto à formulação de políticas culturais e em ações de preservação e difusão.

A visada histórica sobre os estudos de folclore proposta neste artigo nos permite trilhar os caminhos pelos quais o fandango passou a ser tratado como um bem cultural que mobiliza esforços para a sua permanência. Conforme proposto por Cavalcanti (20I2a) ao destacar a importância de uma antropologia dos estudos de folclore, é preciso, contudo, compreendê-los e 
valorizá-los em seu contexto de época como um lugar importante para a apreensão de imagens da nação. Tais estudos integram debates importantes no pensamento social brasileiro e também foram determinantes para o que hoje compreendemos como cultura popular. Antropólogos e pesquisadores contemporâneos das expressões e celebrações populares são inevitavelmente envoltos em campo por sentidos e práticas sociais que evocam abordagens delineadas pelos estudiosos de folclore.

Amparada pela convivência etnográfica com múltiplos atores sociais, privilegio aqui os registros feitos pelos estudiosos de folclore em suas publicações autorais, além de entrevistas e reportagens nos quais se posicionam. Pensando estas fontes documentais como narrativas, proponho situar estes estudiosos como participantes da construção de perspectivas nativas sobre o fandango. A interlocução direta destes autores ou por meio de atores sociais imbuídos de tais leituras teve participação determinante na vida social, colaborando para a configuração de memórias e práticas do que hoje compreendemos como fandango.

\section{O FANDANGO E OS PRECURSORES DO FOLCLORISMO NO BRASIL}

Os primeiros esforços dedicados à pesquisa do folclore nacional caminham no sentido de tentar dar corpo e organizar uma estrutura classificatória para a compreensão de um universo heterogêneo e complexo. Esse empenho classificatório caminha junto com a dificuldade recorrente de apreender e organizar sob uma ótica cientificista os fatos folclóricos. Na abertura de "Música Popular Brasileira", Oneyda Alvarenga, discípula de Mário de Andrade, afirma que o crítico Andrade Muricy teria grande razão ao afirmar que o folclore musical brasileiro seria ainda um "cipoal bravo" (Alvarenga, I960: II). A noção de fandango emerge nesse cipoal com nós não menos difíceis de serem desatados. A imprecisão será marca característica da classificação do termo no desenrolar da bibliografia sob a perspectiva folclórica.

Na história do folclorismo, Silvio Romero (I85I-I9I4) é figura emblemática por seu pioneirismo. Em sua "Vista sintética sobre o folclore brasileiro", que introduz os Cantos populares do Brasil (Romero, I987), o autor distingue duas espécies de festas - as de "igreja popularizadas" e as "puramente populares". A elas acrescenta-se um terceiro conjunto que Romero resume como aquelas em que "o povo" perderia verdadeiramente seu recato. É nesta última categoria que ele situa o fandango: "chama-se xiba na província do Rio de Janeiro, samba no Norte, cateretê na de Minas, fandango nas do Sul, uma função popular na predileção dos pardos e mestiços em geral, que consiste em se reunirem damas e cavalheiros em uma sala ou num alpendre para dançar e cantar" (Romero, I897: 56).

No âmbito dos estudos que buscam mapear aspectos mais gerais do folclore nacional, o fandango dos bailes festivos - mais especificamente o "fan- 
dango sulista"4 identificado geograficamente entre os estados de São Paulo e do Rio Grande do Sul - começará a ser distinguido como uma expressão em que se sobressai a relação entre dança e música. É característico desse momento ainda embrionário da institucionalização do folclorismo o uso de fontes secundárias e o interesse pela origem dos termos que designam as manifestações folclóricas (Pereira, 2006). Os contextos sociais e os interlocutores investigados são muito raramente mencionados, pois predomina a perspectiva nacionalista e a compreensão coletivista dessa produção - o povo, anônimo, em seu conjunto, portador de conteúdos que permitem tracejar um ethos brasileiro.

Dentre os primeiros estudos nos quais o fandango aparece como verbete, destacam-se especialmente História da música brasileira, publicado originalmente em 1926, de Renato Almeida (I895-I98I), e Ensaio sobre a música brasileira, de I928, de Mário de Andrade (I893-I945). Embora as duas obras sejam pioneiras dentre as investigações de maior fôlego sobre aspectos musicais da cultura brasileira, o fandango aparece ligado ao conjunto "danças" (Pereira, 2006), obedecendo a uma classificação mais ampla do folclore nacional e, ao mesmo tempo, reafirmando a ênfase na relação entre música e dança já presente na obra de Romero (1987).

As obras de Renato Almeida e de Mário de Andrade são consideradas referências para o movimento modernista brasileiro no que tange à formação da musicalidade nacional, pois se posicionam criticamente quanto ao cultivo das sonoridades europeias como modelo musical erudito. Contudo, enquanto Andrade "entendia que ainda não havia música artística brasileira devido, principalmente, à não valorização da música popular”, Almeida estava mais preocupado com "a compreensão, por parte dos compositores, de que era preciso desfazer a dualidade existente na arte produzida no Brasil" (Martins, 2009: 67). A perspectiva andradiana foi, sem dúvida, a que ofereceu maiores contribuições à construção de um olhar inclusivo sobre a cultura popular frente à sua histórica marginalização pela sociedade brasileira.

Estudos historiográficos como o de Pereira (I996), ${ }^{6}$ que investiga o processo de morigeração da sociedade paranaense entre os anos I829 e I889, revelam registros de severas proibições aos bailes de fandango no século XIX, acusados de desmedida sensualidade, como sugere a definição de Romero (I987). "Batuques e fandangos" teriam sido realizados com grande frequência nas áreas urbanas e eram considerados sinônimos pela sociedade paranaense, fundidos no que seria uma espécie de "baile popular" associado indistintamente a negros libertos, mulatos livres e brancos pobres. Segundo o autor, o anseio político de reorganização dos costumes da sociedade urbana paranaense no século XIX implicou um arrojado processo de proibição às manifestações populares. Fandangos e batuques, assim como os jongos, teriam sido contundentemente banidos dos meios urbanos, restringindo-se cada vez mais às áreas rurais, onde o controle social ficava a critério dos proprietários de terra. 
Em que pese a perspectiva histórica proposta por Pereira (I996), que ilumina a prática no século XIX, percebemos, pouco a pouco, nos estudos de folclore iniciados no século seguinte, que os fandangos vão deixando de ser relacionados à baderna e ao erotismo, dando lugar à noção de bailes populares de caráter familiar, envoltos em uma atmosfera de respeito e cordialidade. Os trabalhos de Almeida (I926) e de Andrade (I928), apesar de pouco descritivos sobre os contextos de realização dos fandangos, já não mais enfatizam o aspecto lascivo. Embora a obra de Almeida tenha sido publicada originalmente dois anos antes do trabalho de Andrade, muitas das contribuições deste foram incorporadas na segunda edição de Almeida, de 1942 (Martins, 2009), inclusive a definição de fandango proposta por Andrade.

Em Mário de Andrade, a passagem dedicada ao fandango não chega a formar uma dúzia de páginas. Reúne registros musicais em partitura entremeados por curtos parágrafos, mas é pioneira no sentido de trazer notas do próprio autor que permitem reconhecer a realização de investidas em campo. Andrade, contudo, limita-se a informar ao leitor que as pesquisas foram realizadas no município de Cananeia, no litoral de São Paulo. Não há referências sobre a ocasião de sua visita, os interlocutores e as localidades pesquisadas. Seu foco é a investigação musical, utilizando-se de termos técnicos para a análise das partituras, e tratando-as como ferramentas para o estímulo à criatividade dos músicos brasileiros. Apenas podemos nos certificar de que a pesquisa foi realizada pessoalmente pelo fato de ele afirmar ter feito uma de suas colaboradoras repetir várias vezes uma mesma canção para que pudesse confirmar alguns aspectos técnicos (Andrade, I962: 99). Contudo, Andrade abre suas breves páginas com um parágrafo descritivo, que foi reproduzido por muitos outros autores relevantes no cenário de produção de conhecimento sobre o folclorismo,? como, por exemplo, Oneyda Alvarenga (I960) e Câmara Cascudo (I984), além de Renato Almeida.

Fandango em geral é sinônimo de baile. Nele se dança de tudo e principalmente danças regionais figuradas. Tem "fandangos batidos" mais rústicos em que o batepé é obrigatório e os "fandangos bailados" mais chiques em que o batepé é proibido. [...] O canto sempre em falso bordão é tirado no geral pelos instrumentistas. Quem dança não canta. O fandango é sempre cantado (Andrade, 1962:99).

No longo texto ensaístico que precede a exposição de partituras, o fandango é também citado como uma "suíte", ou seja, não como uma totalidade coerente, mas como uma série de danças de origens diversas, justapostas.

O fandango do sul e meio do Brasil se na maioria das vezes é sinônimo de bailarico, função, assustado (aliás, o próprio baile é uma suíte), muitas vezes é uma peça em forma de suíte. A mim me repugnava apenas que suítes nossas fossem chamadas de "suíte brasileira". Porquê não "Fandango", palavra perfeitamente nacionalizada? (Andrade, 1962: 68). 
Por vezes de forma eloquente, Andrade defende que as culturas populares deveriam ser referendadas como manancial criativo para a produção da sonoridade brasileira, propondo a mistura de gêneros e a livre interação, com severas críticas às segmentações regionalistas. Andrade enfatiza que os músicos devem beber diretamente na "fonte das manifestações populares" percorrendo o Brasil e não apenas aquilo que a própria vizinhança oferece (Andrade, I962: 70).

Vemos também emergir na obra de Andrade a perspectiva patrimonial que constituirá uma das tônicas de atuação em defesa das culturas populares no âmbito do Movimento Folclórico Brasileiro e das políticas culturais futuras. No parágrafo que encerra a passagem dedicada ao fandango, Andrade marca sua posição quanto ao aculturamento, esclarecendo que a busca por traços que remetessem às origens europeias - portuguesas e espanholas - estava longe de ser foco de suas preocupações.

Este documento notável, bem como outros fandangos de Cananeia, são incontestavelmente bens nacionais. Foram colhidos de gente caipira dos sítios do arredor da cidade, gente sem nenhum contato a não ser mesmo com outros caipiras brasileiros. É gente que não sabe mais que geração passada teve algum estranho na ascendência (Andrade, 1962: 100).

Já Renato Almeida não tem um olhar tão generoso quanto o de Mário de Andrade em relação à fertilidade das manifestações populares. Enquanto Andrade identifica um ethos brasileiro, que não pode mais ser correlacionado diretamente como o ameríndio e nem simplesmente caracterizado por suas múltiplas origens, Almeida indica um caminho mais longo a ser trilhado. A passagem dedicada ao fandango em sua História da música brasileira tem como enfoque a compreensão das origens do termo e seu processo de difusão a partir das rotas traçadas pelas sociedades ibéricas. Almeida incorpora a definição de Andrade, reconhecendo a originalidade melódica e reafirmando o caráter maleável e impreciso do fandango como baile que reúne danças variadas. Assim, sua preocupação segue, não em explicitar elementos constitutivos de uma totalidade, mas em detalhar algumas dessas danças, dentre as quais configuram chimarrita, cana-verde, dão-dão, quero-mana, nhô-chico e tonta, além de listar uma extensa gama de outras danças não descritas. $\mathrm{Pa}$ rece-me que o autor se utilizou apenas de fontes secundárias, sem fazer menção a qualquer levantamento próprio de dados ou situações de campo.

Guardadas as devidas diferenças, com Mário de Andrade e Renato Almeida o fandango ganha um lugar no mapa do folclore brasileiro. Embora não haja uma preocupação em refletir sobre o contexto de realização e as pessoas que o praticam, tais estudos são responsáveis pelos registros pioneiros de algumas das peculiaridades e características do fandango. No desenrolar dos estudos de folclore, perceberemos que tanto a definição proposta por Andrade quanto a gênese traçada por Almeida serão retomadas nos registros sobre o fandango. 


\section{O REGIONALISMO COMO MARCA DO MOVIMENTO FOLCLÓRICO}

Entre I947 e I964, os estudos de folclore no Brasil ganham institucionalidade demarcando um campo mais abrangente, impulsionado por meio de uma rede de pesquisadores de vários estados, sob o que ficou conhecido como Movimento Folclórico Brasileiro (Vilhena,I997). Um dos aspectos primordiais do período foi a liderança da Comissão Nacional de Folclore, fundada em I947, cuja proeminência foi assegurada por sua articulação a comissões estaduais autônomas. A organização de forma regionalizada dessa rede de estudiosos se reflete nas formulações e pesquisas do folclorismo, definindo processos de coleta e mapeamento que seguiam as divisas convencionais dos estados. Gama (20I2), em seu estudo sobre o processo de criação das primeiras exposições do Museu de Folclore Edison Carneiro, gestado no âmbito do Movimento, destaca que a ideia de nação era apresentada como um todo composto por suas partes.

Enquanto alguns temas eram estabelecidos como canônicos, os próprios intelectuais também demarcavam seus campos e territórios de estudos, algo que acontece de maneira determinante em vários estados (Aguiar, 20I I; Giovannini Jr., 2013; Corrêa, 2013; Silva, 2015). Tornam-se também comuns os inventários regionais de folclore, associando manifestações e objetos populares aos estados onde ocorriam.

De fato, a disposição para a realização de cartografias aparece como um forte apelo desse novo momento do folclorismo brasileiro. Em comunicação apresentada no Simpósio de Folclore Brasileiro, ${ }^{8}$ Ayres da Mata Machado Filho enfatiza que a geografia e a história deveriam ser ciências orientadoras dos estudos de folclore. Ele reconhece que a divisão política e administrativa do Brasil em estados produz sentimentos de regionalismo que moldam culturas. Contudo, mesmo percebendo processos cada vez mais intensos de mobilidade e permeabilidade entre as fronteiras, sugere uma ordem cartográfica orientadora de um grande mapa do folclore brasileiro (Machado Filho, I967: 258).

Na mesma ocasião, Manuel Diégues Júnior expõe suas "Sugestões para a caracterização do folclore brasileiro" e aponta que a "marca regional, tanto quanto no homem, se imprime no folclore" (Diégues Jr., I967: 259). Para o autor, a caracterização regional configuraria um sistema de relações que permitiria o compartilhamento de aspectos culturais. A "base regional" seria, portanto, um elemento fundamental sobre o qual se desenvolve o "fato folclórico"9 e, mesmo reconhecendo semelhanças e variantes por estados, seria esta a base para o estabelecimento de um viés comparativo.

Embora as formulações de Mário de Andrade tenham sido inspiração para temas e estratégias de articulação dos estudos de folclore no Brasil, nota-se que sua proposta de ruptura com o regionalismo não foi levada adiante no âmbito do Movimento Folclórico. Mário de Andrade era favorável à "desgeografização", de forma a compor uma brasilidade sem fronteiras, integrada por traços comuns que perpassam o conjunto, tema que aborda não somente 
em Ensaio sobre a música brasileira, mas também é explicitado em Macunaíma, ambos publicados no mesmo ano (Jardim, 2015: 87). Contudo, a necessidade de pesquisas in loco para que manifestações fossem "vivenciadas" e "coletadas" foi enaltecida pelo Movimento, coadunando-se com o viés regionalista em um momento em que os financiamentos para pesquisas eram escassos. As incursões em campo realizadas por equipes dos próprios estados asseguravam viabilidade ao intuito de recobrir a dimensão territorial brasileira. A organização do Movimento em subcomissões ancoradas no critério regional implicou também a segmentação das próprias expressões folclóricas englobadas pela definição de áreas de atuação estaduais e segmentadas, como procurarei demonstrar seguindo a produção dos estudos de folclore sobre fandango.

\section{O FANDANGO "DO PARANÁ"}

No Paraná, o desenvolvimento de um campo de estudos para o folclore encontrava como grande desafio reconhecer formas próprias que pudessem ser alocadas no escopo do mapeamento do folclore brasileiro. A história de formação do estado remete à participação de muitos grupos de colonos que mantiveram costumes e elos identitários. No panteão dos festejos celebrados em território paranaense constavam danças e músicas que não eram consideradas aculturadas na medida em que resguardavam a origem dos povos imigrantes, tais como alemães, italianos, ucranianos, poloneses etc.

Segundo Vilhena (1997), a Comissão Paranaense de Folclore foi uma das primeiras a se constituir e teve papel muito atuante nos primeiros anos, assumindo a realização do II Congresso Nacional de Folclore, na cidade de Curitiba, em 1953. O secretário-geral da Comissão, José Loureiro Fernandes, era também professor de antropologia e etnografia na Universidade do Paraná, e foi ferrenho defensor do reconhecimento da disciplina folclórica como parte do campo das ciências sociais. Seu posicionamento acabou ampliando diferenças no contexto do Movimento, levando-o a renunciar ao posto de secretário-geral em 1954, após desavenças com Fernando Corrêa de Azevedo. Este era responsável pela seção de folclore do Instituto de Pesquisas da Faculdade de Filosofia da Universidade do Paraná, dirigido por Loureiro, que resolvera "extinguir a seção de folclore do referido instituto, sob alegação de que os estudos de folclore não comporiam uma disciplina distinta, mas seriam apenas uma divisão dos estudos etnológicos" (Vilhena, I997: I42). A medida foi contestada por Azevedo, que acabou conquistando o apoio de todos os demais membros da Comissão Paranaense de Folclore.

A crise entre José Loureiro Fernandes e Fernando Corrêa de Azevedo foi bastante representativa da dificuldade de se encontrar um lugar para os estudos de folclore que, até então, obtinham maior respaldo institucional no campo da arte do que no âmbito das ciências sociais (Vilhena, I997). Fernando Corrêa de Azevedo (I9I3-I975) era favorável à aproximação dos estudos de fol- 
clore com o campo das artes, posicionamento compartilhado por muitos dos membros que participaram da trajetória da Comissão Paranaense de Folclore. Ele foi também um dos primeiros nomes do folclorismo paranaense a se dedicar ao fandango. Descendente de uma tradicional família carioca, era irmão mais novo do musicólogo e folclorista Luiz Heitor Corrêa de Azevedo. ${ }^{\text {Io }}$ Residiu grande parte de sua vida em Curitiba, entre I937 e I97I, onde foi um importante articulador cultural, especialmente interessado por música e folclore.

O autor iniciou suas pesquisas sobre o folclore paranaense em I948, mesmo ano em que foi criada a Comissão de Folclore do Paraná, e realizou viagens ao litoral do estado com fins de "coleta" até I955 ${ }^{\text {II }}$ Seu empreendimento, segundo ele sem grandes pretensões analíticas ou interpretativas, seria uma resposta ao alarmante chamado da Comissão Nacional de Folclore que se dedicava então a arregimentar esforços em todo o país para a realização de registros que salvassem "ao menos a lembrança de nossas mais caras tradições" (Azevedo, I973: 57).

Em 1953, Azevedo participou do II Congresso Brasileiro de Folclore, realizado no Paraná, ocasião em que se apresentaram grupos de pau-de-fita, balainhas, boi-de-mamão e fandango em um festival folclórico na litorânea Paranaguá. Ao relatar tal experiência, ele ressalta que, dos gêneros apresentados, somente o fandango estaria realmente enraizado no Paraná, pois as demais manifestações seriam praticadas apenas por colonos catarinenses que as teriam herdado de seus ascendentes açorianos (Azevedo, I973). O autor identifica, contudo, um traço comum entre o folclore catarinense e o paranaense, qual seja, "uma acentuada tendência para congregar, sob um nome genérico, as mais diversas danças e autos populares" (Azevedo, 1973: 64). Seguindo, portanto, os mesmos passos de Andrade (I962) e Almeida (I942), percebia inicialmente o fandango como um agregado de danças; cana verde, chamarrita, anu, tonta, entre outras.

Já no Caderno de Folclore ${ }^{12}$ dedicado ao fandango do Paraná, publicado postumamente em I978, Azevedo associa o uso da palavra "marca" à distinção entre as diferentes danças e músicas que integram o fandango. Ele afirma ter registrado cerca de trinta marcas, ressaltando ainda a existência de muitas outras com nomenclatura própria a cada região (Azevedo, 1978). Trata-se de um dos primeiros registros escritos do termo "marca", utilizado corriqueiramente entre fandangueiros do Paraná para nomear o conjunto dos diferentes ritmos, melodias e coreografias que se distinguem em um fandango. Isso sugere uma escuta mais atenta de Azevedo aos seus interlocutores em campo que, embora ainda não nomeados, pouco a pouco ganharão identidade nos registros do folclore nacional. A noção de "marca" traz também um sentido mais integrado entre estas danças e músicas até então tratadas como unidades desarticuladas que remetiam a um passado longínquo. 
De fato, uma das grandes contribuições aos estudos sobre fandango oferecida por Azevedo é a elaboração de um extenso inventário das marcas, incluindo esquemas gráficos das coreografias e transcrições das músicas em partitura. Tal levantamento ainda hoje é recorrentemente citado em pesquisas acadêmicas e culturais sobre fandango. O autor, contudo, não explora a diversidade e as variações que ele próprio observa. As marcas são expostas a título de demonstração exemplar, sem grandes apontamentos sobre as possíveis distinções apuradas em sua investigação em campo. Percebemos esse aspecto como uma tendência de muitos autores das pesquisas folclóricas, que fixam suas experiências sem problematizarem contextos e diferenças, ou mesmo as dificuldades encontradas na compreensão dos próprios interlocutores. Esses inventários, contudo, acabaram ganhando um caráter prescritivo da autenticidade do fandango no decorrer de suas releituras por pesquisas que se sucederam, conferindo uma rigidez classificatória que não corresponde à realidade que ele próprio reconhece ter vivenciado em campo.

Os estudos de Azevedo na região de Paranaguá, Morretes e Guaraqueçaba são contemporâneos aos de Inami Custódio Pinto (I930-20I4), folclorista que ganhou grande projeção no Paraná. Natural de Curitiba, passou a infância em Paranaguá, onde conheceu o fandango: "Então eu tinha nove anos, e naquelas noites quentes de Paranaguá, papai, que sempre foi admirador e grande folclorista amador, nos levava no miramar, em Paranaguá, onde você avistava toda a extensão do Rio Itiberê e parte da Ilha dos Valadares. Ele dizia escute Inami: plaplapla papa. Isto é o fandango, é uma dança assim, assim e assim" (Custódio Pinto, em depoimento à equipe de pesquisa do $\mathrm{Mu}$ seu Vivo do Fandango, Curitiba, 2005).

Durante a Segunda Guerra, o pai de Custódio Pinto foi transferido para Santa Catarina. Em 1952 ele retornou ao Paraná e, de volta a Paranaguá, surpreendeu-se com a desarticulação do fandango, que, segundo ele, teria sido alvo de proibições durante o período de guerra. A partir de então, resolveu empreender pesquisas sistemáticas sobre o tema. A forma como se envolveu com o fandango é bastante emblemática da afetividade e identificação com que muitos folcloristas desse período se relacionavam com o campo de pesquisa, procurando afirmar a legitimidade de sua atuação.

A primeira coisa que eu fiz foi correr em Paranaguá pra ver o fandanguinho, porque eu já fazia parte lá em Florianópolis de todos os grupos folclóricos, carnavalescos. Cheguei lá, corri pra lá e cadê? Desapareceu. Daí fui indagando, indagando. [...] Primeiro conheci o Moacir Barbeiro, que tocava com violão, eu disse: "não, não é isso que eu quero". Mas ele tocava todas as marcas de fandango, o Moacir Barbeiro. "Não, mas quem toca é o Manequinho da Viola". Daí ele me passou tudo, eu gravei tudo. Ele sabia mais de quinhentas marcas o danado, e eu gravei mais de quarenta rolinhos num gravadorzinho. Ele foi me explicando e tal, e aquilo. Imagina quando a gente grava, eu era menino e, à medida que ele ia explicando, eu ia vendo tudo aquilo de anos atrás e recordando. Eu parecia integrado na coisa, fazia parte da coisa. O Manequinho disse: "ah, o mestre aí, o vivão lá que conhece todas as marcas" (Custódio Pinto, em depoimento à equipe de pesquisa do Museu Vivo do Fandango, Curitiba, 2005). 
Tão relevantes quanto seus registros foi o intensivo trabalho de articulação local empreendido por Custódio Pinto. Além de músico e estudioso de folclore, ele atuava também como produtor musical e fonográfico em Curitiba. Entre as décadas de I950 e 1960, aproximou-se progressivamente de vários moradores de Paranaguá em busca de conhecedores do fandango, travando amizade em especial com Manequinho da Viola e Romão Costa (ver foto 5 na p. 422).

Eu cheguei em Paranaguá e me disseram: "[o fandango] tá morto e não existe mais". Então o meu esforço foi para desenterrar o folclore. Eu procurava. Ainda existia, mas eram só velhinhos que tocavam fandango. Os mais novos já tinham esquecido ou não chegaram a conhecer o fandango. [...] Até que encontrei Manequinho da Viola, que trabalhou nessa companhia de papai. Por coincidência ele era, e foi considerado até a sua morte em I966, o maior mestre violeiro do fandango de todos os tempos. O Manequinho me indicou Romão, da Ilha de Valadares, que era mestre de dança, muito famoso também. Então, eu levei de I952 a 1966, convencendo ele a tocar fandango, porque ele era pescador, trabalhava na estiva, inclusive sábado, domingo e feriado. [...] Só em I964 eu consegui formar um grupo em Valadares. Eu fiz a seleção de casais oriundos de Tabaruca, do Guaraçu, da Ilha do Teixeira, do Morro dos Ingleses e comecei a ensaiar com o conjunto do Manequinho da Viola. Não deu outra: foi um sucesso! Mas faltava dinheiro para comprar roupas, construir a casinha do fandango (Custódio Pinto, 2004: 227).

A atuação de Custódio Pinto no sentido de propor uma nova forma de continuidade do fandango com a organização de um grupo, até onde se tem notícia, é pioneira na região. ${ }^{13}$ É curioso, entretanto, notar que apesar de afirmar que "somente os velhinhos tocavam", ele consegue reunir muitos jovens e adultos que conheciam as músicas e coreografias (ver foto 6 na p. 423).

A tendência em afirmar que "o fandango está morto" ou "é morto" é algo ainda hoje corriqueiro especialmente entre fandangueiros de idade mais avançada. Esse tipo de fala, além de traduzir um sentimento de nostalgia, é também dotada de forte apelo mobilizador junto ao interlocutor, funcionando como um dispositivo eficaz para atrair o interesse sobre o fandango. $O$ trabalho de fomento ao fandango proposto por Custódio Pinto parece também se utilizar desta estratégia, pautando-se por uma lógica ambígua, que remete à noção de "retórica da perda" proposta por Gonçalves (I997), no sentido de que, ao mesmo tempo em que promovia e incentivava o fandango, Inami apelava ao risco sempre iminente de desaparecimento para formular as demandas. Entre a exaltação de um purismo autêntico e a lamentação por um cenário agonizante, Custódio Pinto amplia as redes de diálogo e articulação do fandango com as autoridades e com a imprensa, figurando como porta-voz das tradições paranaenses e interlocutor dos ilhéus de Valadares, em muitas reportagens alarmantes publicadas em veículos de comunicação no Paraná e em São Paulo. 


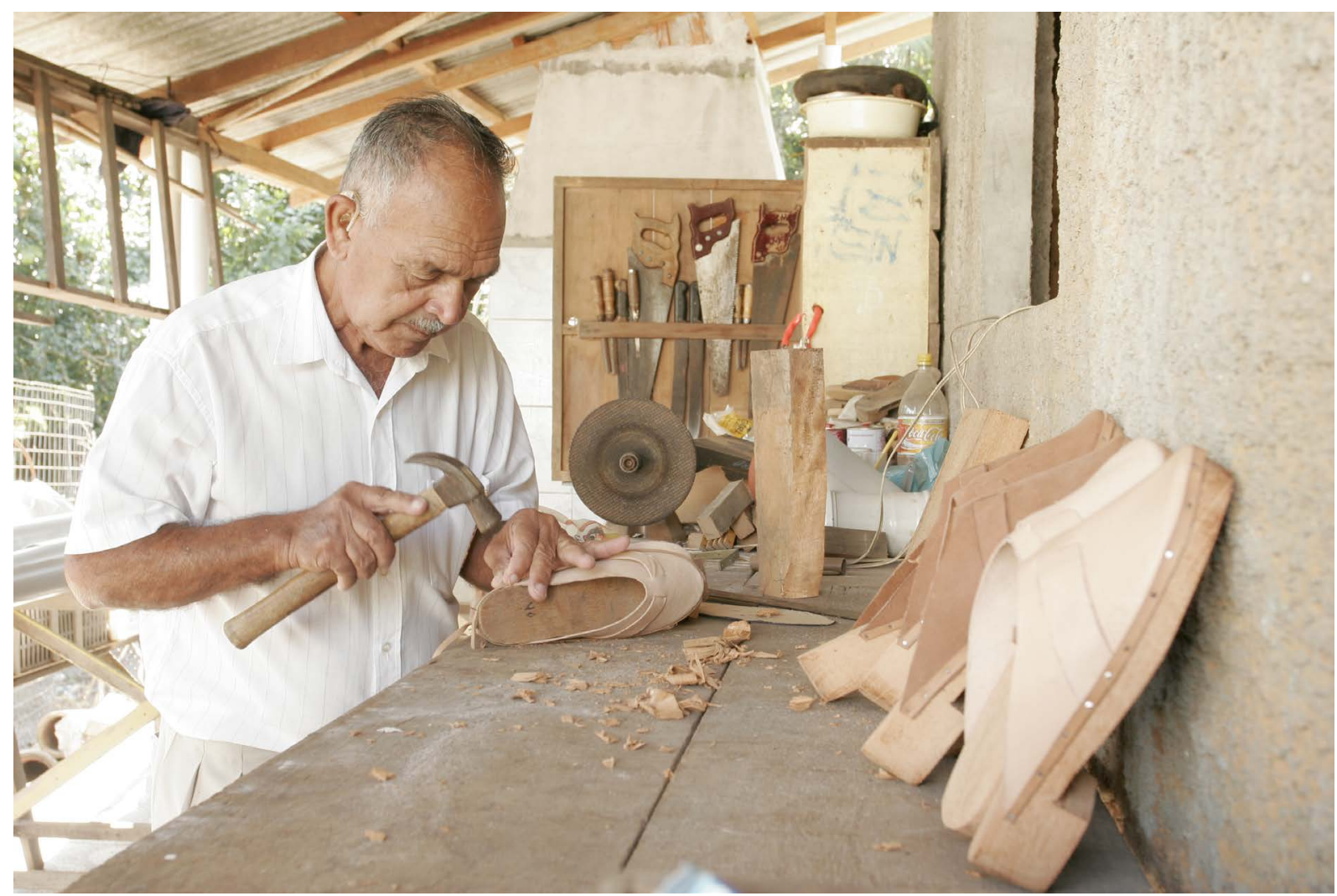

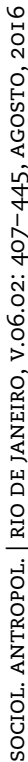

5 .

Varanda, Felipe.

Mestre Romão Costa em sua oficina de

tamancos de fandango na Ilha dos Valadares, em Paranaguá /PR.

Junho de 2005.

Acervo Museu Vivo do Fandango,

Associação Cultural Caburé. 


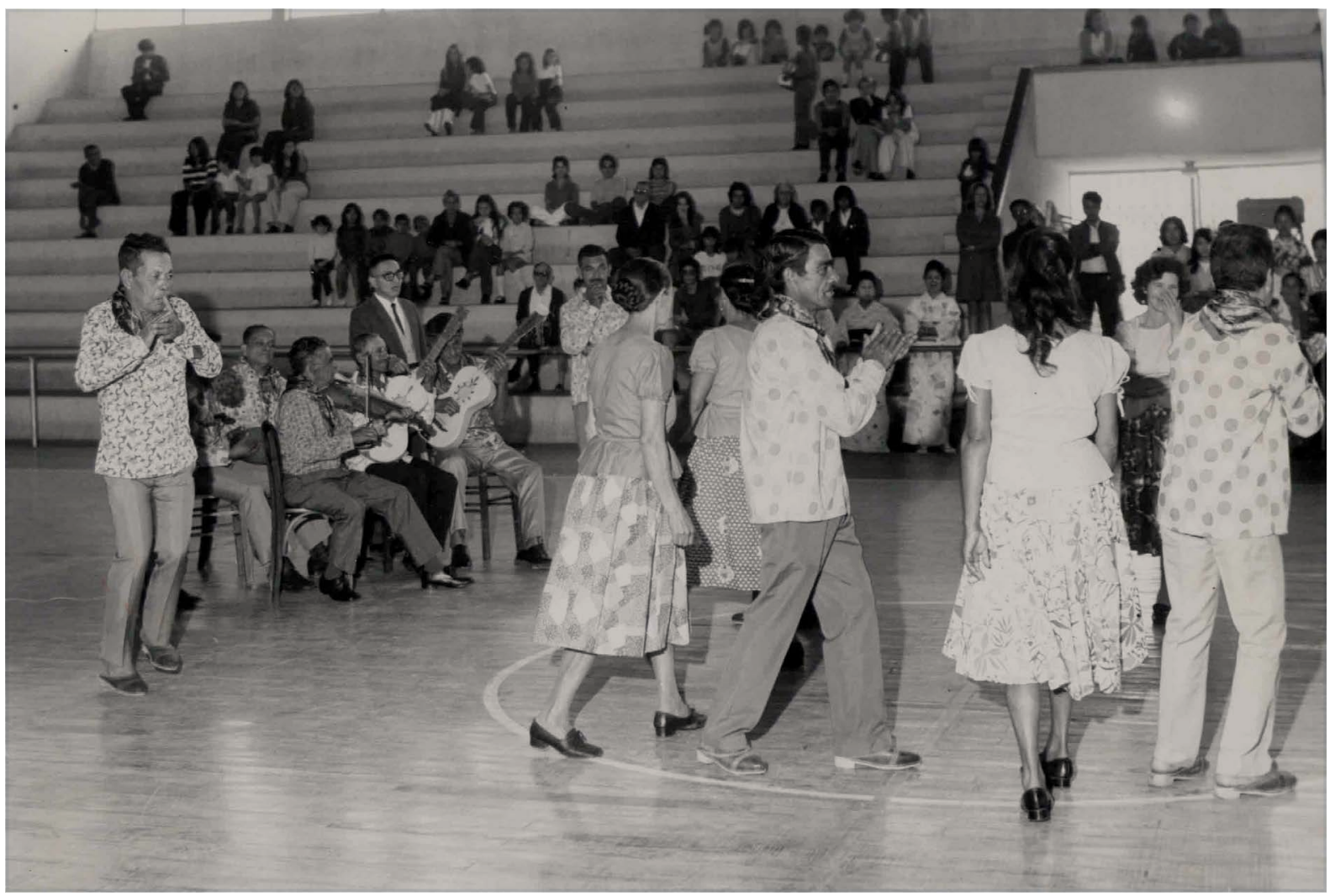

6.

Fotógrafo desconhecido

Apresentação do grupo de fandango formado por incentivo do folclorista Inami Custódio Pinto com Manequinho da Viola

(ao centrodos músicos, tocando viola) e Romão Costa (ao centro dos dançadores). Acervo pessoal de Romão Costa. 
Em I973, o jornal curitibano Correio do Povo publicou a matéria "Folclore - professor fala em extinção", na qual Custódio Pinto declara: "o folclore paranaense, se as coisas continuam como estão, não dura mais de uma geração". Na reportagem ele defendia também a autenticidade do fandango e sua execução feita com instrumentos artesanais como emblema popular paranaense, algo diverso do regionalismo gaúcho, onde a recriação do cancioneiro popular seria feita por músicos eruditos e instrumentos formalizados. Por fim, lamentava: "É uma pena que a gente presencie tudo isso se acabando. Acho que devia pertencer ao patrimônio histórico nacional. Mas se houver, sem demora, uma medida para deter esse fim, teremos salvo uma página de nossa própria história" (Custódio Pinto, Correio do Povo, 23/08/1973).

"Fandango dá seus últimos passos no Paraná" foi tema de reportagem de O Estado de S. Paulo, em I975, que tratava também do padecimento de Custódio Pinto na busca de apoio ao folclore.

Assim como o fandango parece estar com os dias contados, esmagado pelos problemas sociais que vão se avolumando (são poucas as famílias da ilha [dos Valadares] não atingidas pela praga da mortalidade infantil), o único homem que até há bem pouco era capaz de mobilizar os fandangueiros parece, por sua vez, sofrer do mal que afeta a vida dos ilhéus - uma indisfarçada indiferença pelo seu trabalho. De fato, Inami Custódio Pinto parece constituir o exemplo não muito raro do estudioso que não encontra o menor apoio para as suas pesquisas. Com a mesma assiduidade com que vem sendo cotejado por políticos e ex-governadores que auxiliam o fandango em épocas pré-eleitorais, Inami continua sempre sem apoio para realizar um trabalho mais sério. Foi assim várias vezes (Enio Squeff, O Estado de S. Paulo, 05/10/1975).

Segundo Vilhena (1997), desde os primeiros anos do Movimento, a busca por recursos para pesquisas e atividades era um desafio, já que os governos dos estados se interessavam apenas pelo financiamento de eventos e festivais com repercussão pública. Assim, articulações dos folcloristas mais envolvidos com a gestão nacional do Movimento haviam levado à criação por decreto, em 1958, de uma entidade vinculada à administração federal intitulada Campanha de Defesa do Folclore Brasileiro (CNFB), cuja expressiva atuação no início dos anos de I960 acabou enfrentando entraves a partir de I964 (Vilhena, I997). Contudo, segundo Silva (20I5), a Campanha conseguiu editar publicações de referência como a Revista Brasileira de Folclore (I96I-I976) e os Cadernos de Folclore Brasileiro (I964-I986), fundamentando a construção de uma imagem intelectual dos estudos de folclore. Em 1976, a CNFB foi integrada à Fundação Nacional de Arte (Funarte) sob a nova rubrica de Instituto Nacional de Folclore (INF), e os estudiosos de folclore passaram a contar com mais recursos estatais. Novos exemplares dos Cadernos de Folclore foram publicados, consolidando temas de interesse do folclore (Silva, 2015), muitos inclusive editando pesquisas empreendidas em décadas anteriores.

Neste mesmo ano de criação do INF, em I976, o fandango foi representado no exemplar de $n^{\circ}$ I5, intitulado Fandango do Paraná, da coleção Documento 
sonoro do folclore brasileiro, série de discos compactos dedicada ao mapeamento da música folclórica, editada pelo INF/Funarte. As gravações de fandango foram realizadas em I968, por Inami Custódio Pinto com o grupo de Manequinho da Viola, e o disco conta com apresentação de Roselys Vellozo Roderjan, outra expressiva integrante da Comissão Paranaense de Folclore. A marca regionalista é acentuada e o fandango aparece, portanto, como um indicativo de pertencimento que legitima sua versão paranaense. Essas gravações enfatizam o "fato folclórico", figurando a visão coletivista das canções ali registradas, porém os grupos e comunidades participantes aparecem devidamente creditados na ficha técnica de realização do disco.

Custódio Pinto foi também articulador da participação do fandango no mapeamento musical do Brasil empreendido pela gravadora Marcus Pereira Discos entre as décadas de I970 e I980, que resultou em uma coleção de LPs de grande prestígio e repercussão. Os registros musicais reuniam lado a lado manifestações populares e ícones da MPB, reforçando traços e peculiaridades de uma diversidade revelada por meio do regionalismo (Sautchuk, 2006; Aragão, 20II). Diretor da gravadora e curador da série, Marcus Pereira relata seu contato com Custódio Pinto na reportagem "O samba é a desgraça nacional. Fazer música regional é nosso caminho certo" (Correio do Povo, Porto Alegre, 06/03/1977), que enaltece a importância do mapeamento da cultura popular brasileira.

Aos trabalhos de Azevedo e Custódio Pinto no registro do fandango paranaense somam-se as contribuições de Roselys Vellozo Roderjan (I927-?), professora curitibana, mestre em história, que em I965 ingressou na Comissão Paranaense de Folclore, assumindo mais tarde a presidência por longo período. Assim como Custódio Pinto, Roderjan também se dedicou ao ensino do folclore nas diversas instituições onde atuou.

Na produção intelectual de Custódio Pinto e Roderjan, vemos o fandango com um sentido mais articulado, destacando suas performances e aspectos musicais intrínsecos. Ambos têm o cuidado de fazer uso de uma terminologia específica relacionada a expressões nativas de descrição e representação do fandango, sem, contudo, evitarem o modo prescritivo e generalizante adotado também na obra de Azevedo.

O fandango era dançado nos sítios, por ocasião do pixirão quando os vizinhos auxiliavam o dono da casa nos trabalhos de roçada ou plantação. O Fandango de finta (arcaísmo que quer dizer coleta) é feito em qualquer ocasião, bastando que todos colaborem na compra dos preparos. Seus dançarinos chamam-se folgadores ou folgadeiras, porque dançam na folga do sábado para o domingo. O Fandango paranaense é formado de uma série de danças denominadas marcas, variando a coreografia conforme o nome delas (anu, andorinha, chamarrita, domdom, tonta, cana-verde, sabiá, caranguejo, lajeana, vilão de lenço, xarazinho, xará grande, marinheiro etc.). $O$ acompanhamento musical é feito com duas violas, uma rabeca e um adufo (pandeiro), confeccionados pelos próprios caboclos. Os cantos são tirados pelos dois violeiros, em vozes paralelas, e podem ser 
tradicionais ou improvisados. Algumas danças são valsadas, executadas arrastando os pés, e outras, sapateadas (batidas ou rufadas), entremeadas de valsados e palmas. O sapateado é feito pelos homens, com tamancos especiais, e as mulheres dançam arrastando os pés, atentas à coreografia. Os sapateados finais são chamados de arremate e seguem-se ao grito de um dos violeiros - "Ô de casa!" (Roderjan, I98I: 30, grifos do autor).

Roderjan divergia de Custódio Pinto sobre a inserção do fandango no Paraná. Enquanto ele defendia a contribuição direta de espanhóis e portugueses que aportaram em Paranaguá, ela acreditava que sua difusão teria partido de açorianos da costa paulista, reconhecendo, assim, haver alguma aproximação com o fandango de São Paulo, não mencionada nas pesquisas de seus colegas folcloristas do Paraná.

O Fandango do litoral paulista é o que mais se afiniza com o Fandango paranaense. Autores paulistas fazem constantes referências ao Fandango do Paraná, citando que nossos caboclos iriam até as cidades e povoados do vizinho estado, nas romarias, para baterem o Fandango. Alceu Maynard Araújo escreve que, na afinação da viola, só os antigos gostavam de usar o ponteado do Paraná e que deixaram de usar porque era muito difícil de temperar. Essa e outras referências são evidências da interligação das danças do Fandango do litoral de São Paulo e do Paraná (Roderjan, I98I: 30, grifos do autor).

Conforme a perspectiva de Roderjan, o fandango do Paraná não se funde, entretanto, com o fandango paulista, estão no máximo correlacionados, como se a divisa entre os estados fosse algo concreto, que demarcasse tradições distintas. De fato, embora os folcloristas do Paraná tenham construído a trajetória de institucionalização desse campo em seu estado articulados com a Comissão Nacional de Folclore e com um cenário intelectual e cultural mais amplo, percebemos que há um interesse em preservar a delimitação de sua área específica de estudos. A capacidade de realização da Comissão Paranaense contrastava com um campo de atuação que reconheciam como limitado, afinal muitas das tradições folclóricas que circulavam no estado eram tratadas como culturas dos imigrantes e, portanto, não eram consideradas parte do escopo de interesse do folclorismo. ${ }^{\mathrm{I} 4}$ Talvez por isso os membros da Comissão Paranaense tenham se voltado com tanta força para aquilo que podiam reconhecer nas esferas de seu pertencimento. A maneira como divulgam o fandango, sempre sob a ameaça de um fim próximo, também transparece como um receio sobre as possibilidades e limites de seu próprio campo de atuação. Ao defenderem o fandango, ao mesmo tempo enaltecem e socorrem o folclorismo paranaense, construindo a si mesmos como estudiosos do tema no cenário nacional. 


\section{O FANDANGO NO MAPA DO FOLCLORE PAULISTA E A CARACTERIZAÇÃO DO HOMEM RURAL}

Em São Paulo, além de presente na obra de Mário de Andrade (I962, I975, I989) e de sua discípula Oneyda Alvarenda, o fandango figura com destaque nas obras de Alceu Maynard Araújo (I9I3-I974) e Rossini Tavares de Lima (I9I5I987), dois nomes emblemáticos do folclorismo paulista e nacional.

Araújo percorreu uma extensa trajetória ligada à educação, tendo obtido o título de doutor em Antropologia Social na Escola Livre de Sociologia e Política, onde a etnografia e os métodos de pesquisa antropológica ganharam relevância, especialmente a partir de I939, quando Donald Pierson tornou-se professor (Cavalcanti, 2009). Auxiliar de Donald Pierson e Emilio Willens e, mais tarde, também professor da Escola, Alceu Maynard Araújo se dedicou ao longo da vida tanto aos estudos de comunidade e às pesquisas sociológicas como aos estudos de folclore. Desempenhou um trabalho de fôlego que extrapolou a perspectiva regionalista, publicando, dentre outros, três volumes dedicados ao Folclore Nacional. Edison Carneiro ressalta que, assim como Câmara Cascudo, Araújo, mesmo tendo se ligado às Comissões de Folclore, preferia desenvolver seus trabalhos com maior autonomia (Carneiro, I962).

Entre 1946 e 1947, Araújo desenvolveu estudos de campo sobre a dança do fandango em Cananeia, no litoral sul paulista. Seu texto apresenta termos como "sociabilidade" e "histórias de vida" e o fandango aparece também como "reunião social" (Araújo, 2004: I64-I67). Contudo, seu viés acadêmico não se sobrepõe ao olhar romântico e idealista, capaz de enxergar de forma apaixonada o campo de estudos ao qual se dedica.

Costuma-se dizer que o povo da roça é um povo triste e indolente e que seus cantos são tristonhos. Entretanto, são inexatas tais afirmações eivadas de etnocentrismo. O nosso rurícola não é triste nem tampouco indolente. A indolência que lhe atribuímos é certamente devido à comparação que fazemos como nosso modus vivendi, governado pela rigidez mecânica e inflexível dos ponteiros do relógio. Somos mais tristes do que eles, pois vivemos a comprar a nossa alegria, as nossas diversões, nas filas dos cinemas etc. O rurícola sabe aproveitar muito bem as horas de lazer. Depois de um dia de trabalho, de um mutirão, que é um jogo coletivo, vêmo-lo "rufar" os pés num fandango, a noite toda, sem dar mostras de enfado ou cansaço. As suas modas são alegres e jocosas, buliçosas, inspiradas nas coisas cotidianas, às quais emprestam um sabor satírico. Suas músicas se nos apresentam tristes porque é a nossa própria alma que decanta a saudade de algo que foi nosso e hoje não mais temos, isto é, aquela plenitude de vida em contato com a natureza que o caipira e o caiçara ainda possuem. Cananeia, com seu luar inigualável, com suas crianças brincando de roda nas ruas, seus pescadores cantando em seus barcos sob o ritmo undiflavo ${ }^{15}$, aquele conjunto de harmonia, cor, luz e singeleza, quase chega a dificultar o pesquisador que se sente envolvido numa atmosfera de poesia e romance (Araújo, 2004:I46-I47).

No mapeamento de Araújo, mais uma vez, o fandango aparece classificado como dança brasileira, acompanhado de inventário de cerca de vinte 
danças que presenciou em bailes de fandango realizados em Cananeia. A narrativa de Araújo elucida contextos de pesquisa, descreve interlocutores e tenta criar pontes entre o fandango e outras manifestações no litoral norte e no interior de São Paulo, procurando similitudes para além da nomenclatura. Embora sejam breves apontamentos, ele confronta sua experiência em Cananeia com a de outros lugares, sendo, portanto, menos prescritivo e generalista do que as notas de Azevedo (1975, 1978). Araújo tece ainda comentários sobre o estreitamento das relações entre fandangueiros do Paraná e de São Paulo, relatando que aqueles participavam anualmente da romaria de Bom Jesus de Iguape, no litoral paulista, época em que eram feitos muitos fandangos.

Alceu Maynard Araújo foi contemporâneo de Fernando Corrêa de Azevedo nas pesquisas de campo sobre fandango e nas atividades junto ao Movimento Folclórico, contudo, talvez em função da dinâmica regionalista que organizava a atuação em torno do folclore nacional, não parece ter havido colaborações mútuas entre suas pesquisas. Já com as pesquisas em território paulista feitas por Mário de Andrade, Araújo (2004: I6I) cotejou dados, comparando seus registros de dandãos com notas feitas em I928 por Mário de Andrade (I962), identificando modas semelhantes.

As pesquisas de Rossini Tavares de Lima no litoral paulista são posteriores àquelas de Araújo e se desenvolveram sob o anseio de uma investida em campo com território delimitado, equipe multidisciplinar e estrutura mais ampla. Em 1959, como membro da Comissão Paulista de Folclore, ele demandou à Campanha de Defesa do Folclore Brasileiro recursos para um levantamento do folclore em municípios do litoral norte com enfoque nas seguintes danças e folguedos: Fandango, Chiba, Caiapó, Congada, Boizinho, Folia do Divino e Folia de Reis. Seu intuito seria o de realizar, após essa primeira etapa, novas investidas no litoral sul, mas os recursos viabilizados somente recobriram a primeira, no litoral norte.

A equipe de pesquisa organizada compreendeu múltiplas habilidades. Rossini Tavares de Lima esteve à frente na função de coordenador e relator, acompanhado de três pesquisadores de campo, um fotógrafo, um cinegrafista, um técnico de gravação e ainda dois folkmusicistas. ${ }^{16}$ Embora os resultados registrados em produção textual coletiva no livro $O$ folclore do litoral norte de São Paulo tenham um caráter mais de inventário do que propriamente de análise, a preocupação com o rigor e a formalidade investigativa é notória. Tais registros descrevem de forma pormenorizada as técnicas de utilização dos instrumentos, afinações e recursos utilizados pelos músicos e desenhos esquemáticos de algumas das danças presenciadas. A riqueza de detalhes contrasta, entretanto, com a impressão de "decadência" das danças registradas por parte da equipe. Limitam-se, contudo, à utilização de dados recolhidos em campo, sem menção a outras pesquisas já desenvolvidas, nem mesmo as de Alceu Maynard de Araújo. 
Um aspecto relevante das pesquisas desenvolvidas por Araújo e Tavares de Lima se refere a uma maior preocupação em caracterizar o homem e seu meio social. Os estudos do folclore paranaense estavam mais preocupados com a manifestação em si, sua origem e sua forma. Em $O$ folclore do litoral norte de São Paulo, Tavares de Lima e sua equipe assim descrevem a população litorânea paulista:

[...] moderadamente mestiçada e possui como tipo característico o caiçara ou mameluco do litoral, que difere do morador das praias a oeste de Santos ou do mixuango fluminense pelo predomínio do branco ibérico sobre os outros elementos. Difícil é estabelecer a contribuição de sua etnia. Entretanto, seja racial e mesmo culturalmente falando, a maior parece ser a de portugueses. Os africanos que, em 1835, correspondiam a 37,6 por cento da população, e hoje não chegam a 8, deixaram contudo, profundas marcas na cultura caiçara. [...] na atualidade, seu habitante, um tanto isolado, possui um baixo nível de vida, exercendo, na maioria, suas atividades como pescador e agricultor, em precárias condições. Planta mandioca, banana, cana-de-açúcar etc., as duas primeiras pela importância que possuem para a sua subsistência. A principal atividade do caiçara, porém, é mesmo a pesca, no geral realizada com técnicas primitivas. Ultimamente, no entanto, chega a exercer outras funções, em consequência do turismo que se alastra pela região. Na zona rural e até mesmo pelas cidades e bairros mais desenvolvidos, é comum vê-lo, franzino e magro, com camisa e calça, chapéu de palha à cabeça, pés descalços. Sua casa é quase na generalidade feita de pau-a-pique e apresenta no interior alguns pobres trastes domésticos (Tavares de Lima et al, I98I: 2I).

$\mathrm{Na}$ caracterização do folclore, percebemos que é recorrente uma dualidade que distingue o homem do interior e do litoral. Nos estudos de folclore paranaense essa tipificação aciona categorias mais genéricas como "praieiros" e "caboclos" - a primeira relacionada ao meio e a segunda à mestiçagem do branco com o índio. Já a terminologia que predomina nos estudos sobre fandango em São Paulo dialoga com os termos "caiçara" e "caipira", categorias que foram também temas de estudo das ciências sociais e que, ainda hoje, participam intensamente do contexto social do fandango. (ver foto 7 na p.430 e foto 8 na p. 43I) 


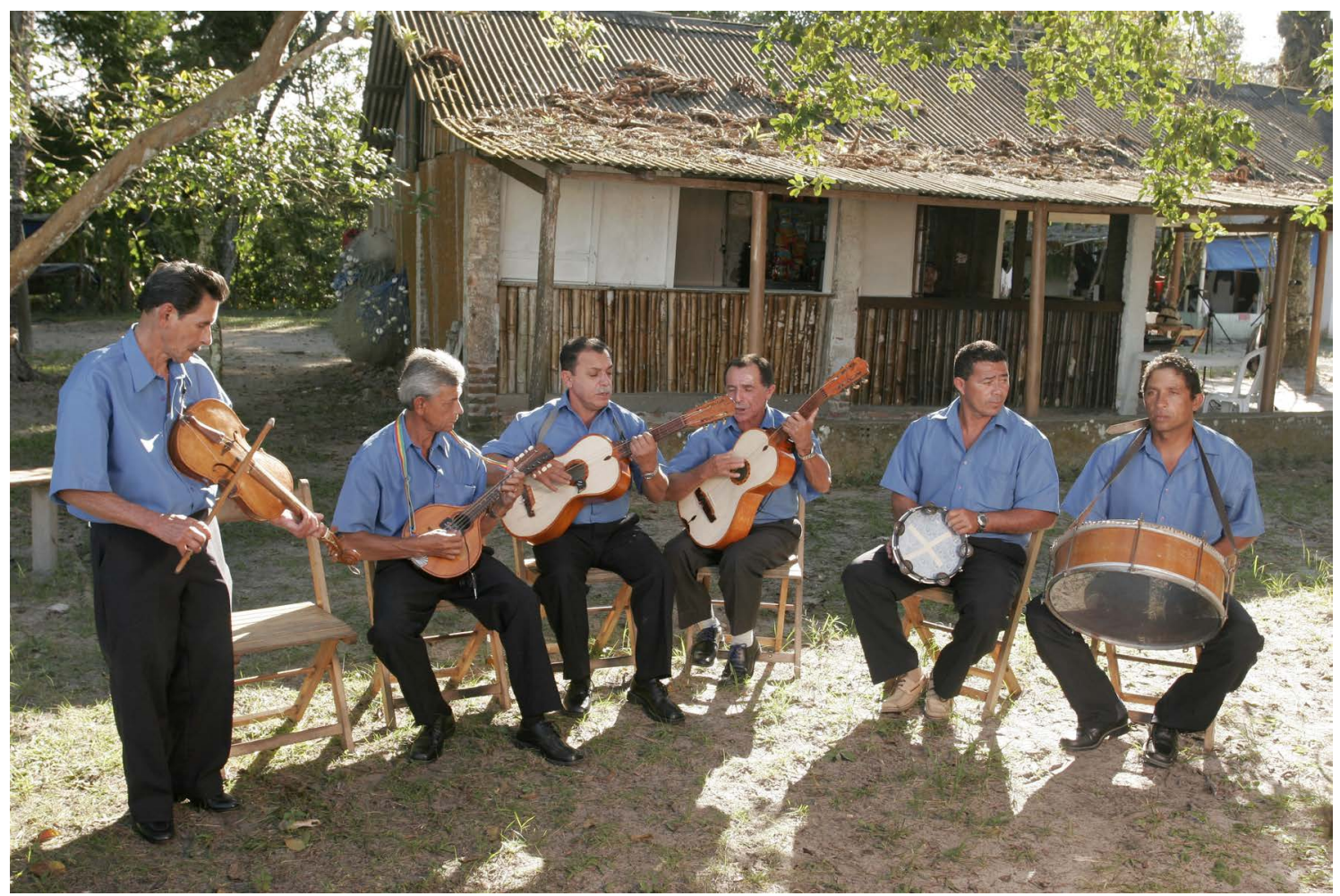

Varanda, Felipe.

Grupo Violas de Ouro de São Paulo Bagre, de Cananeia/SP, o primeiro grupo de fandango formalmente constituído na litoral paulista, na década de I990, por estímulo ao um convite à participação no programa Viola, minha Viola, apresentado por Inezita Barroso, na TV Cultura.

Junho de 2005.

Acervo Museu Vivo do Fandango, Associação Cultural Caburé. 


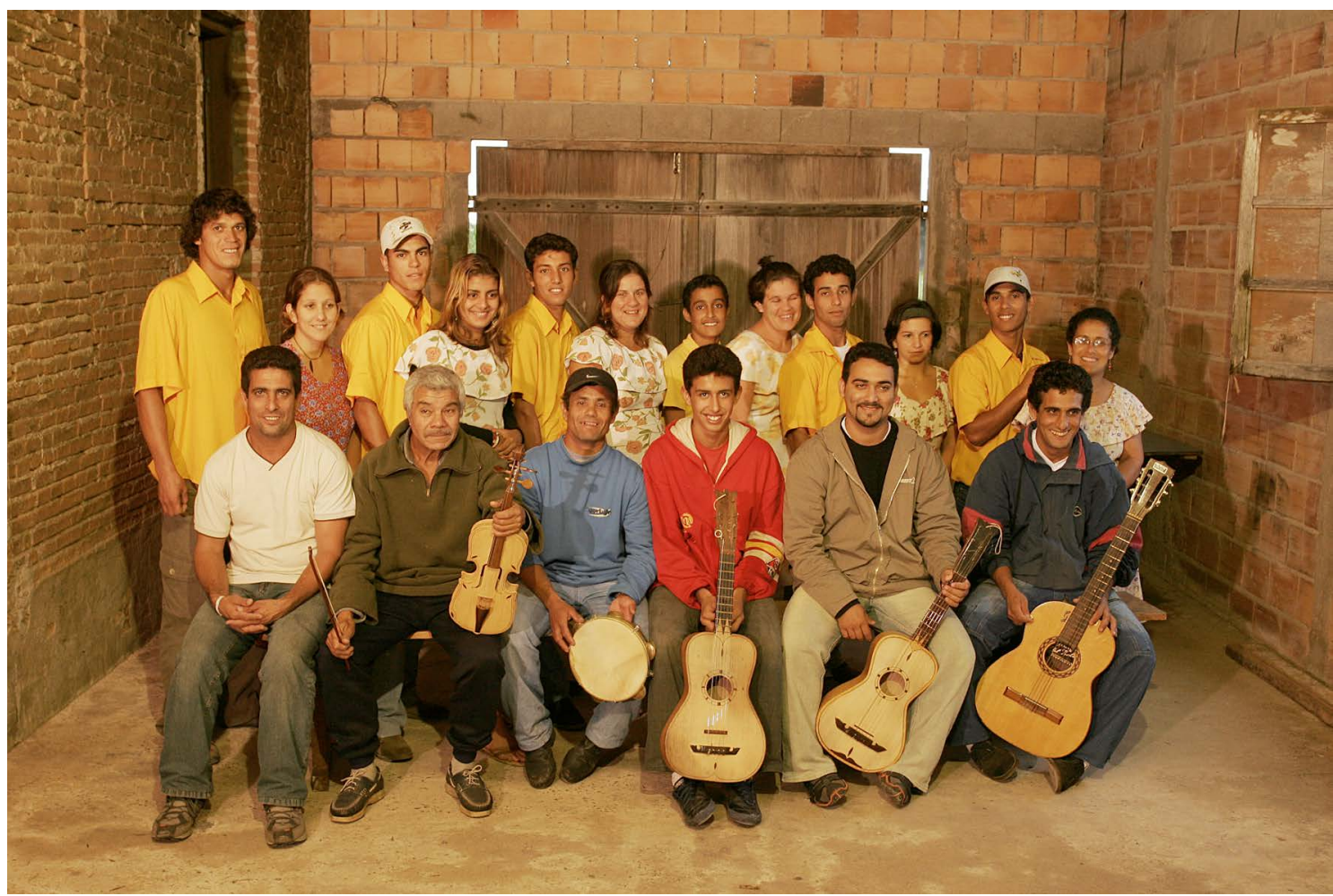

8.

Varanda, Felipe.

Grupo de fandango formado por integrantes da Associação Jovens da Juréia, entidade sediada em Iguape/SP. que atua em prol de comunidades caiçaras na região onde foi criada na década de I980 a Estação Ecológica da Juréia Itatins, unidade de conservação que restringe a presença de moradores tradicionais.

Junho de 2005.

Acervo Museu Vivo do Fandango, Associação Cultural Caburé. 
Entre os anos de I930 e I960, no processo de formação das ciências sociais no Brasil, as noções de "caiçara" e de "caipira" ganharam lugar no ambiente acadêmico, em especial entre os estudos de comunidade, em pesquisas desenvolvidas por Emilio Willens (2003), Antonio Candido (200I), Gioconda Mussolini (I980), entre outros. Em que pesem as diferenças de métodos e abordagens entre os estudos de comunidade e os estudos de folclore, ambos caracterizam-se pela prática etnográfica, valorizando a presença do pesquisador em campo para o conhecimento do objeto de estudo. Tais estudos floresceram no Brasil em um período de fronteiras acadêmicas mais suaves e de intenso trânsito intelectual. Em São Paulo, a confluência entre os estudos de folclore e os debates sobre o pensamento social foi ainda mais intensa no processo de organização do campo das ciências sociais, haja vista o trabalho pioneiro empreendido por Mário de Andrade, Claude e Dina Lévi-Strauss na articulação da Sociedade de Etnografia e Folclore, fundada em 1936, da qual participaram intelectuais que transitavam amplamente entre as ciências sociais e os estudos de folclore (Soares, I983; Valentini, 2010). Talvez por esta configuração intelectual, o fandango tenha emergido de modo muito diferente nas pesquisas folclóricas realizadas em São Paulo, figurando apenas como parte de processos culturais e sociais mais amplos que caracterizam certos modos de vida de populações tradicionais "caiçaras" ou "caipiras". Já nos estudos paranaenses, o fandango emergiu como uma expressão singular que conquista contornos estéticos e classificatórios cada vez mais precisos, tornando-se emblemática da própria ideia de "folclore paranaense".

\section{ALGUMAS CONSIDERAÇÕES}

Em seu estudo sobre o Movimento Folclórico Brasileiro, Vilhena (I997) analisou os motivos do fracasso da almejada consolidação da disciplina folclórica como campo específico no ambiente acadêmico. O distanciamento entre os estudos de folclore e as ciências sociais perpassam divergências de projetos institucionais, métodos e modelos de ciência. Como efeito deste processo de distanciamento, as ciências sociais relutam em reconhecer estes estudos como parte do processo histórico de sua consolidação como disciplina e, por certo tempo, afastaram-se dos próprios temas abarcados pela noção de folclore (Vilhena, I997; Cavalcanti, 2012a). Contudo, conforme destaca Cavalcanti (2012a), o dinamismo e a permanência destas expressões e práticas associadas à concepção de folclore acabaram por tornar inevitável o interesse de novas gerações de cientistas sociais em tomá-las como campo de investigação.

Isso faz com que os fatos folclóricos sejam re-integrados nas análises contemporâneas carregados de ilusão, em especial a ilusão do arcaísmo. Eles são ainda fortemente vistos como, de alguma forma, correspondendo a sobrevivências de outrora, indicando difusamente níveis primitivos de nossa própria forma de ser, as tão decantadas "raízes". Ora, esse tipo de visão, sub-repticiamente integrado nos estudos contempo- 
râneos sobre o assunto, produz o eficaz efeito de sedução e exotização característicos do arcaísmo: a ideia de que esses fatos chegaram, ou deveriam ter chegado, até nós tal e qual foram no passado (Cavalcanti, 2012b: 371-372).

Com efeito, esse aspecto nostálgico se reflete não apenas em novas pesquisas, mas também nas narrativas daqueles que estão envolvidos com o fandango. São falas que enaltecem tempos antigos, em geral imprecisos, e que se ressentem de conhecimentos e saberes não mais praticados, mesmo diante da vitalidade da prática contemporânea do fandango, em uma indissolúvel tensão entre passado e presente. As narrativas de memória remetem a tempos de exuberância e harmonia, e o risco do desaparecimento é uma das principais argumentações que fundamentam as demandas de apoio, como se o fandango vivesse sob um contínuo processo de subtração. O exercício de retomar a trajetória de construção social do fandango como tema de interesse nos permite compreender a dinâmica do fandango na atualidade, as formas de sociabilidade que produz e suas estratégias de inserção em outras esferas na vida social.

Percebemos que as perspectivas pelas quais o fandango foi registrado e elaborado na trajetória dos estudos de folclore estão simultaneamente presentes em sua compreensão contemporânea marcando dualidades e tensões. O enaltecimento das origens europeias, recorrente nos registros paranaenses, convive com a perspectiva de enraizamento especialmente simbolizada pela noção de cultura caiçara, enfatizada em meio às pesquisas realizadas em São Paulo, que ganhou ainda maior relevância a partir das décadas de I960 e I970 no contexto de disputas territoriais em lutas contra a especulação imobiliária e a expulsão de populações nativas por meio da criação de unidades de conservação ambiental na região litorânea (Diegues, 2000, 2004; Pimentel, 20I0).

A noção da fandango como um bem nacional que aparece originalmente em Mário de Andrade (I928) também caminha lado a lado com a perspectiva regionalista acentuada pelo Movimento Folclórico. Este aspecto simultaneamente local e nacional aparece hoje nas políticas de registro do patrimônio imaterial brasileiro, que retomam e atualizam algumas práticas de inventário e salvaguarda inauguradas pelo Movimento. O fandango, registrado em 2012 pelo IPHAN, após um longo processo dialógico com as comunidades locais, foi cunhado pela nomenclatura "fandango caiçara", tendo o seu sítio identificado no litoral dos territórios paulista e paranaense (Corrêa, 2013).

No Paraná, a interação de fandangueiros com folcloristas foi intensa e produziu novas formas de organização da sociabilidade festiva caracterís tica do fandango. Os folcloristas procuraram traduzir, por vezes de maneira prescritiva, traços que apontavam uma suposta autenticidade do fandango paranaense. Algumas das características do fandango são enfatizadas e construídas nesse processo de interação, como, por exemplo, um certo tipo de 
moralidade, que para os folcloristas seria fruto do aspecto iminentemente familiar do fandango em um notável contraste com os registros disponíveis para o século XIX.

Vianna (1995) indicou a importância da participação de intelectuais na inserção do samba em outras esferas da vida social como fator que contribuiu para a sua notoriedade como emblema nacional no início do século XX. Vimos a existência de processo semelhante, ainda que sob o recorte estadual, conduzido pelos folcloristas paranaenses no que tange à emergência do fandango como emblema de uma identidade popular tradicional do Paraná. Quase todos os nomes expressivos do folclorismo paranaense se envolveram ao longo de suas vidas em atividades pedagógicas e, portanto, tiveram grande influência na formação de um olhar sobre o fandango. Contudo, a interação dos folcloristas com seu campo de pesquisas abriga tensões, pois, na medida em que tentam apoiar e incentivar o fandango, acabam por intervir nas dinâmicas próprias de organização social que conferiam à manifestação o aspecto "espontâneo" que tanto prezavam. Para os folcloristas do Paraná, o desenho ideal do fandango como expressão autêntica e harmônica de famílias caboclas e litorâneas parece flutuar num lugar incerto no tempo, fruto de construções ideológicas, situando-se após sua conformação nacionalizante e antes dos efeitos avassaladores da modernidade.

Embora o fandango seja uma expressão comum em territórios litorâneos contínuos do Paraná e de São Paulo, muitos aspectos distinguem sua construção social e territorial de um estado para o outro. Enquanto no Paraná percebemos a busca de uma identificação mais ampla com um projeto de identidade cultural para o estado no conjunto da nação e a ênfase em suas peculiaridades artísticas e culturais, em São Paulo o fandango é visto de modo menos nítido como participante de certos nichos identitários específicos que compõem a formação da cultura tradicional paulista. Os próprios folcloristas paranaenses e paulistas ocupavam lugares distintos nos cenários artístico e intelectual local. No Paraná, é notório o vínculo dos estudiosos de folclore com o campo das artes, já os folcloristas paulistanos têm maior trânsito nos campos de confluência entre o folclore e as ciências sociais.

É relevante notar que grande parte dos folcloristas alerta para a carência documental e para a necessidade de ampliar os mapeamentos sobre o folclore no país. Contudo, tal percepção não parece ter gerado diálogos mais sistemáticos entre a vasta bibliografia produzida. Recorrentemente o fluxo de informações citado pelos diferentes autores se refere somente às definições de terminologia e raramente se cotejam os dados obtidos nas pesquisas de campo. Parece haver nos estudos de folclore uma tensão produzida por certo sentimento de insuficiência das pesquisas somado a uma ansiedade em reunir dados que estão sempre prestes a se perder. Em certa medida, tal visão se perpetua na atualidade das políticas públicas de patrimônio cultural ima- 
terial, em práticas que reforçam a urgência da documentação de certas manifestações populares, sob pena de perda irreparável de informações. De fato, esse sentimento pode se justificar, especialmente, porque a lógica de trabalho ainda segue processos muito semelhantes, com ênfase na coleta de material. Assim, pessoas ligadas às práticas populares são recorrentemente entrevistadas em projetos de documentação muitas vezes similares. Por outro lado, há verdadeiramente um caráter inesgotável em qualquer processo de documentação, já que o repertório humano, e suas variações entre a memória e a inventividade, jamais será apreendido nas pesquisas sobre o fandango com a mesma complexidade que podemos experimentar no convívio com seus praticantes.

Cabe ainda salientar algumas peculiaridades da atuação do folclorista Inami Custódio Pinto junto ao fandango no Paraná. É notório o longo período de sua vida que dedicou ao tema, envolvendo-se de forma significativa em redes locais de relações, especialmente em Paranaguá, e travando amizades com os fandangueiros Manequinho da Viola e Romão Costa. Essas relações parecem ter sido também determinantes nas construções e mudanças de seu próprio olhar sobre o fandango, ampliando seu comprometimento com o campo e as pessoas que dele participavam. Apontamos, assim, que o ethos foclorista proposto por Vilhena (I997) - que o autor formula a partir das redes de cordialidade entre estudiosos, celebradas em congressos e festivais, e também das formas de participação e identificação dos estudiosos com os temas e objetos do folclore - pode ser também pensado, em alguns casos, a partir de influências dos próprios interlocutores nas trajetórias intelectuais de estudiosos, ampliando, desta forma, nosso entendimento sobre o escopo das redes de relações e influências mútuas formadas pela concepção de folclore. 
Joana Ramalho Ortigão Corrêa é doutoranda e mestre pelo Programa de Pós-Graduação em Sociologia e Antropologia da Universidade Federal do Rio de Janeiro (PPGSA/UFRJ) e bolsista Conselho Nacional de Desenvolvimento Científico e Tecnológico (CNPq). Também é gestora cultural e atuou como uma das coordenadoras do Museu Vivo do Fandango, pesquisa que envolveu a organização de uma rede patrimonial relacionada ao fandango caiçara no litoral sul de São Paulo e norte do Paraná.

Suas áreas de interesse são ritual e performance, estudos de folclore, cultura popular, patrimônio imaterial e políticas culturais. É coautora do livro Museu vivo do fandango (2006) e co-organizadora do livro-CD Na ponta do verso: poesia e improviso no Brasil (2008). 


\section{NOTAS}

I Este artigo é um desdobramento do primeiro capítulo de minha dissertação de mestrado intitulada Vamos fazer um fandango: arranjos familiares e sentidos de pertencimento em um dinâmico mundo social (PPGSA/UFRJ, 20I3) com orientação da Profa. Maria Laura Cavalcanti e banca composta pelos Profs. Marco Antonio Gonçalves e Renata de Sá Gonçalves. Também revi e aprofundei algumas das questões em comunicações orais apresentadas na oficina de pesquisa Antropologia dos Estudos de Folclore, coordenada pela Profa. Maria Laura Cavalcanti (RISU/PPGSA, 20I4), e no Fórum de Antropologia e Estudos de Folclore coordenado pelos Profs. Oswaldo Giovannini Jr. e Wagner Chaves (REA/ABANNE, 20I5). A todos agradeço pelas leituras, oportunidades e comentários ao trabalho.

2 Especialmente os municípios de Guaraqueçaba, Paranaguá e Morretes, no Paraná; Cananeia e Iguape, em São Paulo.

3 Pereira (2006), em "Breve bibliografia comentada sobre o fandango sulista: de dança brasileira a baile caiçara dos litorais do Paraná e de São Paulo" propõe a organização da bibliografia produzida sobre o fandango sulista a partir de três grandes períodos que configuram temas e perfis de interesse: (I) "relatos de viajantes e naturalistas; (II) "estudos de folclore e cultura popular", que subdivide em primeiros estudos e estudos monográficos, e (III) estudos contemporâneos, com ênfase em investimentos mais sistemáticos em campo. O presente artigo deve em muito à organização e análise preliminar dos estudos sobre folclore feitos pelo antropólogo e amigo Prof. Edmundo Pereira.

4 É importante ressaltar que os autores envolvidos nos processos de mapeamento do folclore brasileiro diferenciam duas categorias de fandango. Além do fandango identificado entre os estados do Sul-Sudeste, registram também um outro fandango da região Norte-Nordeste, relacionado às cheganças e marujadas. Embora a nomenclatura seja similar, não são traçadas aproximações entre ambos.

5 Há, em ambas as publicações, também outro tópico dedicado às "danças dramáticas".

6 Pereira fundamenta sua pesquisa na legislação dos municípios paranaenses durante o período imperial. 
7 Em artigo sobre os folguedos do boi no Brasil, Cavalcanti (20I2b) chama a atenção para a vitalidade das pesquisas e publicações de Mário de Andrade na construção da ideia de dramaticidade como aspecto essencial dessas manifestações. Embora não corresponda por completo ao fato vivo, a perspectiva andradiana de "auto dramático" foi a tal ponto tomada como referência para definição da brincadeira do boi que, ainda hoje, pode ser percebida nos relatos de seus próprios atores sociais como celebração de um passado ideal afetado pela modernidade.

8 O Simpósio foi instalado em 25 de agosto de 1967 , sob a presidência de Renato Almeida, realizado pelo Instituto Brasileiro de Educação, Ciência e Cultura/UNESCO. Algumas comunicações foram transcritas na Revista Brasileira de Folclore, 7/I9, set./dez. de I967 - edição comemorativa dos vinte anos de existência da Comissão Nacional de Folclore.

9 Segundo a Carta do Folclore Brasileiro (I95I): "constitui o fato folclórico a maneira de pensar, sentir e agir de um povo, preservada pela tradição popular e pela imitação, e que não seja diretamente influenciada pelos círculos eruditos e instituições que se dedicam, ou à renovação e conservação do patrimônio científico humano, ou à fixação de uma orientação religiosa e filosófica".

Io Sobre as pesquisas de Luiz Heitor Corrêa de Azevedo, ver Mendonça (2007) e Barros (2013).

I I Segundo o autor, suas pesquisas (ou "coletas") foram realizadas nas seguintes colônias de pescadores da baía de Paranaguá: Costerinha (foz do rio Guaraguaçu), Pontal do Sul (praia do Leste, no Município de Paranaguá) e rio do Medeiros. Seus estudos foram publicados sob o título "Aspectos Folclóricos do Paraná", em 1975, nos Cadernos de Artes e Tradições Populares, 2, do Museu de Arqueologia e Artes Populares da Universidade Federal do Paraná. A parte sobre fandango foi reeditada sob o título de "Fandango do Paraná" como conteúdo do Caderno de Folclore, 23, da Campanha de Defesa do Folclore Brasileiro, em I978.

I 2 Segundo Silva (20I5), os Cadernos de Folclore foram publicados de I96I a I986, primeiramente pela Campanha de Defesa do Folclore Brasileiro, depois renomeada Instituto $\mathrm{Na}$ - 
cional de Folclore, ajudando a consagrar grandes temas de interesse do folclore nacional, bem como seus estudiosos.

I3 A proposta de formação de grupos a partir da reunião de praticantes e conhecedores de fandango foi posteriormente seguida por Helmosa Salomão Richter, professora e entusiasta do folclore na cidade de Morretes. Na década de I970, ela reuniu moradores de bairros rurais do município para a formação de um grupo que passa também a ser representante da cultura paranaense em eventos e festivais até mesmo fora do estado. A partir da década de I990 muitos grupos são formados na região, como o Violas de Ouro de São Paulo Bagre, de Cananeia (SP), o Grupo Folclórico Mestre Romão, em Paranaguá, com jovens dançadores de Paranaguá (PR). Atualmente, há uma grande profusão de grupos, cada qual a seu modo, somente com músicos, incluindo ou não a presença de dançadores, e até mesmo só com dançadores e música mecânica.

I 4 Em 2004 coordenei, juntamente com Claudia Marcia Ferreira, diretora do Centro Nacional de Folclore e Cultura Popular, uma reunião em Curitiba, no Paraná, preparatória para o I Seminário Nacional de Políticas Públicas para as Culturas Populares, realizado em 2005, em Brasília, pelo Ministério da Cultura. Na ocasião, evidenciou-se que o posicionamento das expressões folclóricas imigrantes no cenário paranaense ainda era um tema delicado e polêmico. Havia representantes de grupos de dança e casas de descendentes de imigrantes (italianos, alemães, ucranianos e espanhóis) que destacavam sua nacionalidade brasileira e, portanto, reivindicavam sua participação nas políticas para as culturas populares formuladas no Brasil.

I5 Termo poético, que tem ondas ou reflexos áureos.

I6 Os folkmusicistas foram o maestro Cesar Guerra Peixe e a pesquisadora Kilza Setti, que publicou posteriormente, em 1984, uma extensa etnografia da música popular caiçara no litoral norte de São Paulo, fruto de seu doutoramento em Antropologia Social na Universidade de São Paulo. 


\section{REFERÊNCIAS BIBLIOGRÁFICAS}

Aguiar, Luciana de Araújo. (200I). Celebração e estudo do folclore brasileiro: o Encontro Cultural de Laranjeiras/Sergipe. Dissertação de Mestrado. PPGSA/Universidade Federal do Rio de Janeiro.

Almeida, Renato. (I942). História da música brasileira. Rio de Janeiro: Briguiet.

Alvarenga, Oneyda. (I960). Música popular brasileira. São Paulo: Editora Globo.

Andrade, Mário de. (1989). Dicionário musical brasileiro. São Paulo: Edusp/Itatiaia.

Andrade, Mário de. (1975). Aspectos da música brasileira. Brasília/São Paulo: Martins/INL.

Andrade, Mário de. (I962). Ensaio sobre a música brasileira. Brasília: Martins.

Aragão, Helena. (20II). Mapeamentos musicais no Brasil: três experiências em busca da diversidade. Dissertação de Mestrado. Cpdoc/FGV. Rio de Janeiro.

Araújo, Alceu Maynard. (2004). Fandango. In: Folclore nacional: danças, recreação e música. São Paulo: Martins Fontes (vol. II). Azevedo, Fernando Corrêa de. (1973). Aspectos folclóricos do Paraná. Cadernos de Artes e Tradições Populares, p. 57-IOI (vol. I).

Azevedo, Fernando Corrêa de. (1978). Fandango do Paraná. Cadernos de Folclore, 23. Rio de Janeiro: Ministério da Educação e Cultura.

Barros, Felipe. (2013). Música, etnografia e arquivo nos anos 40: Luiz Heitor Corrêa de Azevedo e suas viagens a Goiás (I942), Ceará (I943) e Minas Gerais (I944). Rio de Janeiro: Multifoco.

Candido, Antonio. (200I). Os parceiros do Rio Bonito. São Paulo: Duas Cidades.

Carneiro, Edison. (1962). Evolução dos estudos de folclore no Brasil. Revista do Folclore Brasileiro, 3, p. 47-62.

Cascudo, Luis da Câmara. (1984). Dicionário do folclore brasileiro. Belo Horizonte: Itatiaia.

Cavalcanti, Maria Laura V. de Castro. (2012a). Por uma antropologia dos estudos de folclore. In: Reconhecimentos: 
antropologia, folclore e cultura popular. Rio de Janeiro: Aeroplano, p. I50-I79.

Cavalcanti, Maria Laura V. de Castro. (2012b). Tempo e narrativa nos folguedos do boi. A ilusão do arcaísmo nos estudos de folclore. In: Reconhecimentos: antropologia, folclore e cultura Popular. Rio de Janeiro: Aeroplano, p. 350-38I. Cavalcanti, Maria Laura V. de Castro. (2009). Introdução. In: Nogueira, Oracy (org.). Vozes de Campo de Jordão: experiências sociais e psíquicas do tuberculoso pulmonar no estado de São Paulo. Rio de Janeiro: Ed. Fiocruz, p. I3-28.

Cavalcanti, Maria Laura V. de Castro \& Vilhena, Luiz Rodolfo P. (20I2). Traçando fronteiras. Florestan Fernandes e a marginalização do folclore. In: Cavalcanti, Maria Laura V. de Castro. Reconhecimentos: antropologia, folclore e cultura Popular. Rio de Janeiro: Aeroplano, p. IO2-I47.

Corrêa, Joana. (2013). Vamos fazer um fandango: arranjos familiares e sentidos de pertencimento em um dinâmico mundo social. Dissertação de Mestrado. PPGSA/Universidade Federal do Rio de Janeiro.

Corrêa, Joana; Gramani, Daniela \& Pimentel, Alexandre (orgs.). (2006). Museu vivo do fandango. Rio de Janeiro: Associação Cultural Caburé.

Custódio Pinto, Inami. (2004). Manual do folclore. In: Souza Neto, Manoel J. de (org.). A [des]construção da música na cultura paranaense. Curitiba: Quatro Ventos, p. 436-487.

Custódio Pinto, Inami. (2003). O fandango na ilha de Valadares. In: Brito, Maria de Lourdes (org.). Fandango de Mutirão. Curitiba: (s.e.), p. 53-6r.

Custódio Pinto, Inami. (I992). Fandango do Paraná. Curitiba: Ed. UFPR.

Diegues, Antônio Carlos. (2004). A mudança como modelo cultural: o caso da cultura caiçara e a urbanização. In: Diegues, Antonio Carlos (org.). Enciclopédia caiçara: o olhar do pesquisador. São Paulo: Hucitec/Nupaub-CEC/USP, p. 2I48 (vol. I).

Diegues, Antônio Carlos. (2000). O mito moderno da natureza intocada. São Paulo: Hucitec/Nupaub-CEC/USP.

Gama, Rita. (2012). A cultura popular no Museu de Folclore Edison Carneiro. Rio de Janeiro: Aeroplano. 
Giovannini Jr., Oswaldo. (2012). Sortilégios do registro: Aires da Mata Machado, os cantos vissungos e os negros do garimpo em Minas Gerais. Tese de Doutorado. PPGSA/Universidade Federal do Rio de Janeiro.

Gonçalves, José Reginaldo. (1997). A retórica da perda. Rio de Janeiro: Ed. UFRJ.

Jardim, Eduardo. (2015). Mário de Andrade: eu sou trezentos. Vida e obra. Rio de Janeiro: Edições de Janeiro.

Machado Filho, Ayres da Mata. (1967). Áreas Folclóricas, em Relação à Divisão Política, Administrativa e Geográfica do País. Revista Brasileira de Folclore, 7/19, p. 254-259.

Martins, Marcelo Adriano. (2009). Duas trajetórias, um modernismo musical? Mário de Andrade e Renato Almeida. Dissertação de Mestrado. PPGSA/Universidade Federal do Rio de Janeiro. Mendonça, Cecília. (2007). A Coleção Luiz Heitor Corrêa de Azevedo: música, memória e patrimônio. Dissertação de Mestrado. Programa de Memória Social/Universidade Federal do Estado do Rio de Janeiro.

Mussolini, Gioconda. (1980). Ensaios de antropologia indígena e caiçara. Organização de Edgar Carone. Rio de Janeiro: Paz e Terra.

Pereira, Edmundo. (2006). Breve bibliografia comentada sobre o fandango: de dança brasileira a baile caiçara. In: Corrêa, Joana; Gramani, Daniella \& Pimentel, Alexandre (orgs.). Museu vivo do fandango. Rio de Janeiro: Ed. Caburé, p. I92-I97.

Pereira, Magnus Roberto de Mello. (I996). Semeando iras rumo ao progresso. Curitiba: Ed. da UFPR.

Pimentel, Alexandre. (2010). Da desterritorialização à re-significação: a r-existência dos caiçaras da Juréia. Dissertação de Mestrado. Programa de Pós-Graduação em Geografia da Universidade Federal Fluminense.

Roderjan, Roselys Velloso. (I98I). Sobre as origens do fandango paranaense. Boletim da Comissão Paranaense de Folclore. Curitiba: Funarte, p. IO-I5.

Roderjan, Roselys Velloso. (1979). As origens do fandango paranaense. Semana de Estudos sobre a Cultura Paranaense. Apostila do curso de folclore. Curitiba: Secretaria do Estado da Cultura e do Esporte, p. 50-55. 
Romero, Silvio. (I897). Cantos populares do Brasil. Rio de Janeiro: Livraria Francisco Alves.

Sautchuk, João Miguel. (2006). O Brasil em discos: nação, povo e música na produção da gravadora Marcus Pereira. Dissertação de Mestrado. PPGAS/Universidade de Brasília.

Silva, Ana Teles. (2015). Na trincheira do folclore: intelectuais, cultura popular e formação da brasilidade - I96I-I982. Tese de Doutorado. PPGSA/Universidade Federal do Rio de Janeiro. Soares, Lélia. (1983). Mário de Andrade e o folclore. In: Mário de Andrade e a Sociedade de Etnografia e Folclore no Departamento de Cultura da Prefeitura do Município de São Paulo, I936-I939. Rio de Janeiro/ São Paulo: Funarte/INF/Secretaria Municipal de Cultura.

Tavares de Lima, Rossini et al. (I98I). O folclore do litoral norte de São Paulo. Rio de Janeiro/ São Paulo: MEC/SEAC/-Funarte/INF.

Valentini, Luísa. (2010). Um laboratório de antropologia: um encontro entre Mário de Andrade, Dina Dreyfus e Claude Lèvi-Strauss (1935-1939). Dissertação de Mestrado. FFLCH, Universidade de São Paulo.

Vianna, Hermano. (I995). O mistério do samba. Rio de Janeiro: Zahar/Ed. UFRJ.

Vilhena, Luís Rodolfo. (I997). Projeto e missão: o movimento folclórico brasileiro (I947-I964). Rio de Janeiro: Funarte/Ed. FGV.

Willens, Emilio. (2003). A Ilha de Búzios: uma comunidade caiçara do sul do Brasil. São Paulo: Hucitec.

\section{MATÉRIAS CONSULTADAS NA HEMEROTECA DA BIBLIOTECA AMADEU AMARAL/CNFCP/IPHAN:}

Paraná faz festival para mostrar folclore. Vicente Ulandovski. O Estado do Paraná, Curitiba, I968.

Legítimo Folclore paranaense é representado pelo fandango. Gazeta do Povo, Curitiba, 31/08/1975.

Folclore - professor fala em extinção. Correio do Povo, Porto Alegre, 23/08/1973.

Fandango dá seus últimos passos no Paraná. Enio Squeff. O Estado de S. Paulo, 05/Io/I975. 
A CONSTRUÇÃO SOCIAL DO FANDANGO COMO EXPRESSÃO CULTURAL POPULAR

444

Contato com a civilização destrói o folclore do litoral. O Estado de S. Paulo, 26/ıo/ı975.

Fandango do Paraná. Inami Custódio Pinto. O Estado de S. Paulo, 26/ıo/ı975.

O último fandango, antes que desapareça. Reportagem sem referência, 29/05/1980.

O samba é a desgraça nacional. Fazer música regional é nosso caminho certo. Margarida Autran. Correio do Povo, Porto Alegre, 06/03/1977. 
Palavras-chave Estudos de folclore;

Cultura popular; Fandango; São Paulo;

Paraná.

Keywords

Folklore studies; Popular culture;

Fandango;

São Paulo;

Paraná

\section{A CONSTRUÇÃO SOCIAL DO FANDANGO COMO EXPRESSÃO CULTURAL POPULAR E TEMA DE ESTUDOS DE FOLCLORE}

\section{Resumo}

O artigo propõe um olhar antropológico sobre a profunda participação dos estudos de folclore e de categorias usadas por estes estudiosos nas construções de sentido e dinâmicas do fandango, expressão popular comum no litoral sul e sudeste brasileiro, especialmente nos estados do $\mathrm{Pa}$ raná e de São Paulo. Revisitando obras e processos de pesquisa empreendidos por Mário de Andrade, Renato Almeida, Fernando Corrêa de Azevedo, Inami Custódio Pinto, Alceu Maynard Araújo, Rossini Tavares de Lima, entre outros, procuro elucidar, a partir do fandango, suas diferentes concepções e projetos no tratamento dado a questões, estratégias e práticas caras ao folclorismo, como patrimonialização, regionalismo, risco, rumor e resgate. Proponho ainda pensar sobre como tais autores articularam, cada um em seu tempo e a seu modo, os estudos de folclore com os campos das artes e das ciências sociais.

THE SOCIAL CONSTRUCTION OF THE FANDANGO AS A POPULAR CULTURAL EXPRESSION AND THE THEME OF FOLKLORE STUDIES

\section{Abstract}

This article proposes an anthropological reading of the broad participation of Folklore studies and the categories used by Folklore scholars in constructing the meaning and dynamics of the Fandango, a popular cultural expression in the Southern and Southeastern Brazilian coast, particularly the states of Paraná and São Paulo. Taking the Fandango as a reference, the work and research carried out by Mário de Andrade, Renato Almeida, Fernando Correa de Azevedo, Inami Custodio Pinto, Alceu Maynard Araújo, Rossini Tavares de Lima, and others are revisited. The analysis aims to illuminate the different conceptions and projects held by these authors regarding issues, strategies and practices typical of Folklorism such as patrimonialization, regionalism, risk, rumor and rescue. I propose, in addition, a reflection on how each of them, in his own context and manner, articulated Folklore Studies with the fields of the Arts and Social Sciences. 